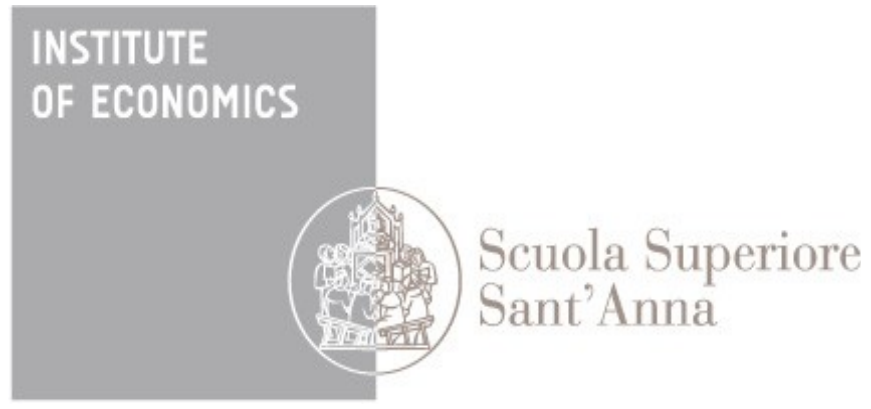

LEM | Laboratory of Economics and Management

Institute of Economics

Scuola Superiore Sant'Anna

Piazza Martiri della Libertà, 33 - 56127 Pisa, Italy ph. +3905088.33 .43$

institute.economics@sssup.it

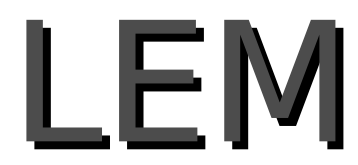

Working Paper Series

\title{
Determinants of Productivity Gap in the European Union: A Multilevel Perspective
}

\author{
Randolph Luca Bruno ${ }^{a, b, c}$ \\ Elodie Douarin ${ }^{a}$ \\ Julia Korosteleva a \\ Slavo Radosevic ${ }^{\text {a,d }}$
}

a University College London, School of Slavonic and East European Studies, UCL Centre for Comparative Study of Emerging Economies, UK.

b IZA Bonn Institute of Labor, Germany.

c Rodolfo DeBenedetti Foundation, Milan, Italy.

${ }^{d}$ Visiting Fellow at Higher School of Economics St Petersburg, Russia.

\section{9/25}

ISSN(ONLINE) 2284-0400

August 2019 


\title{
Determinants of Productivity Gap in the European Union:
}

\section{A Multilevel Perspective*}

\author{
Randolph Luca Bruno ab \\ Elodie Douarin ${ }^{a}$ \\ Julia Korosteleva ${ }^{a}$ \\ Slavo Radosevic ${ }^{\text {ac }}$
}

\begin{abstract}
The paper explores the determinants of productivity gap within the European Union in four industrial manufacturing sectors (computers, chemicals, basic metals and food) of strong macroeconomic significance and varied 'Research and Development' (R\&D) intensity. Our analysis reveals that some of the most important factors determining productivity gap across the EU are related to technology gap variables - R\&D intensity and R\&D embedded in purchased equipment and machinery - and how they interact. While the signs for both R\&D and embedded R\&D are as expected and our results emphasise the relevance of technology for closing the productivity gap, this is not the case with the interaction between these two variables. The estimates for the interaction terms are indeed very significant and consistently negative in three out of four sectors. This negative relationship suggests that there is no complementarity between these two modes of technology acquisition - R\&D and embedded R\&D investments - which are however each separately crucial for catching up. In policy terms, this situation suggests that there is a lack of coordination between R\&D policy and technology transfer (FDI, trade and industrial policy). Given that, our results also show a widening productivity gap between the countries of the EU periphery (South and East) and the rest of the sample.
\end{abstract}

JEL Classification: L60, O33, C55

Keywords: productivity, technology gap, multilevel analysis, European Union

\footnotetext{
*Research at the basis of the paper was funded by the European Union Horizon 2020 Research and Innovation action under grant agreement No 822781, GROWINPRO (https://cordis.europa.eu/project/rcn/218765/factsheet/en). Early stages of this research were supported by the UCL SSEES Centre for Comparative Study of Emerging Economies (https://www.ucl.ac.uk/ssees/research/research-centres-and-seminar-series/ucl-centre-comparative-studiesemerging-economies).

We are extremely grateful to Kirill Osaulenko for outstanding research assistance in all stages of this research. Previous versions of this paper have been presented at 'Schumpeterian Society Conference 2018' in Seoul, at Sant'Anna School of Advanced Studies in 2018, at the 'EMAEE 2019 Economics, Governance and Management of Al, Robots and Digital Transformations' conference at University of Sussex and at the University of Greenwich 2019 workshop on 'Innovation, firm dynamics, employment and growth: New developments in modelling and estimation'.

a) University College London, School of Slavonic and East European Studies, UCL Centre for Comparative Study of Emerging Economies.

b) IZA Bonn Institute of Labor and Rodolfo DeBenedetti Foundation.

c) Visiting Fellow at Higher School of Economics St Petersburg.
} 


\section{Introduction}

The European Union (EU) was once described by the World Bank as a 'convergence machine' (Gill \& Raiser 2012). However, since 2008, its performance has been a mix of positive and negative phenomena. The Eurozone crisis led to large job losses in manufacturing in the EU periphery, especially in the EU South, where it accentuated a trend started even well before 2008 (Timmer et al. 2010). Some 'new' member states from Central and Eastern Europe, especially Visegrad-5, have joined the German-Austrian manufacturing core (IMF, 2013), while the South of the EU has been deindustrialising at an accelerated pace. Overall, pre- and post-2008, we observe a strong differentiation amongst EU-28 economies on 'core' and 'periphery' (Landesmann et al., 2015) ${ }^{1}$. This structural differentiation is reflected in increasing divergence in labour productivity (Filippetti and Peyrache, 2013) which has been followed by a slowdown in productivity growth in the EU as a whole (van Ark, O'Mahony, and Timmer, 2008). These trends have been taking place against the backdrop of slowed down economic growth and productivity globally (The Conference Board, 2018). The overall context in which the productivity gap in the EU has been increasing is defined as 'great divergence' (OECD 2018).

Post-2008, there are signs that the EU convergence machine might still work, but it is 'not working for everyone' and it is thus in need of an 'upgrade' (Ridao-Cano and Bodewig, 2018). The productivity divide has been pronounced between EU North and South EU while it seems that the convergence machine is 'back in full swing in Central and Southeast Europe (CEE)' (ibid). There seems to be distinctive polarisation in the production structures of 'core' countries (such as Germany and Austria) and southern 'periphery' countries (Greece, Italy, Spain and Portugal) (Gräbner et al. 2017; Gräbner et al. 2018).

There are diverse interpretations of the ongoing divergences in the EU28. Without ambition to be comprehensive about different theoretical discourses, we note three groups of explanations. The first group is strongly macroeconomic cum institutional focusing on the shortcomings of institutional architecture in a European Monetary Union without a fiscal and political union (e.g. De Grauwe, 2012; Boyer, 2014). A second group emphasises differences in structural reforms and supply-side policies between different EU macro-regions (South vs. North vs East) using indicators like Doing Business, skills and education etc. (e.g. Ridao-Cano and Bodewig, 2018). The third group of explanations can be termed 'structuralist' cum Schumpeterian, attributing the differences between EU macro-regions by differences in their capacities to generate technology. For example, Gräbner et al. (2017) and Gräbner et al. (2018) focus on polarisation in industrial structures as manifested in differences in technological capabilities: the emergence of export-driven growth in the core and debt-driven growth in the periphery. Similarly, the technology gap approach to growth posits that differences in levels of development are eventually rooted in the levels of technological development (Fagerberg and Verspagen, 2014).

\footnotetext{
${ }^{1}$ Gräbner et al (2018) argue that the focus on a dichotomy of core and periphery countries in the existing literature might fall short of explaining the nuances of current developmental trajectories in Europe. They develop a taxonomy consisting of core, periphery, financialised and Eastern European catch-up economies which they consider more suitable in order to understand the evolutionary process that has been triggered by European integration.
} 
Our approach in exploring the issue of productivity gap in Europe is eclectic, methodologically new and empirical. First, we note that technology generation capacities cannot be isolated from the institutional and developmental ones, i.e. macro-regional features of economies, and thus it is not an issue of either/or but how different factors of growth interact. Second, the multi-level approach in exploring determinants of productivity gap represents a methodological novelty worth pursuing. We analyse at sectoral level but also use firm, sub-sector/sector and country level variables. Third, in addition to common variables as explanatory factors of productivity gap, we also use a proxy for two modes of technology acquisition - technology embedded in imported machinery and equipment (embedded R\&D) and in-house R\&D.

A novelty of our approach is that we explore the determinants of total factor productivity (TFP) in a multi-level framework by combining firm, industry and country level determinants. This is a substantial departure from the literature, where determinants of TFP have been explored only at either country level, or only at sectoral or micro levels. By using a multi-level framework, we can estimate the impact of all factors nested within each other. We are not aware of a paper that tries to integrate all three levels of analysis or determinants into one framework.

Against this backdrop, our main contribution can be summarised as follows. First, we provide an analysis of productivity growth in the EU with a focus on firm-level data at a disaggregated level and setting one common EU-wide productivity frontier to allow for a cross-country comparison. Second, we use a multilevel model to control for sector-specific and country-specific factors ${ }^{2}$. This allows us not only to identify the relative importance of factors at different levels, and to discuss how contextual factors impact on productivity, but also to account for possible clustering effects of firms within sectors and countries, when failing to do this may lead to misleading results. Third, we extend the understanding of the Schumpeterian growth process by investigating the interplay between subsectoral in-house R\&D and embedded R\&D processes. Our results evidence the importance of technology gap variables and specifically the two modes of technology acquisition - own R\&D intensity of firms and countries and R\&D embedded in purchased equipment and machinery - and how they interact. While the signs for both own R\&D and embedded R\&D are positive as expected, the interaction between these two variables is not. Very significant, and consistently negative, interactions between own and embedded R\&D across three of our four sectors suggest that there is no complementarity between these two modes of R\&D, even though they are independently important precondition for catching up. Our results are robust to different specifications accounting for firm unobserved heterogeneity and sampling. These conclusions have far-reaching policy implications, which we discuss in the conclusions.

In section 2, we discuss the EU productivity challenge drawing a few stylised facts forming the basis of our exploration. In section 3, we review the broader literature on determinants of productivity, productivity and technology gap, which can help us in guiding our empirical research. In section 4, we present our data and report on descriptive statistics giving critical stylised facts relevant to our analysis. In section 5, we report on econometric results. In section 6, we draw conclusions and policy implications.

\footnotetext{
${ }^{2}$ For example, technology gap models are by and large macro models. See for recent example Cimoli et al (2019).
} 


\section{Background: The EU productivity challenge}

The EU productivity challenge is twofold. First, the declining rate of EU productivity growth is part of a secular decline in productivity observed for most developed countries. The magnitude of the phenomenon can be evidenced in relation to the US, as a technology leader, and is verified for all EU macro-regions (figure 1)

Figure 1: Average TFP growth rates: EU macro-regions versus the US

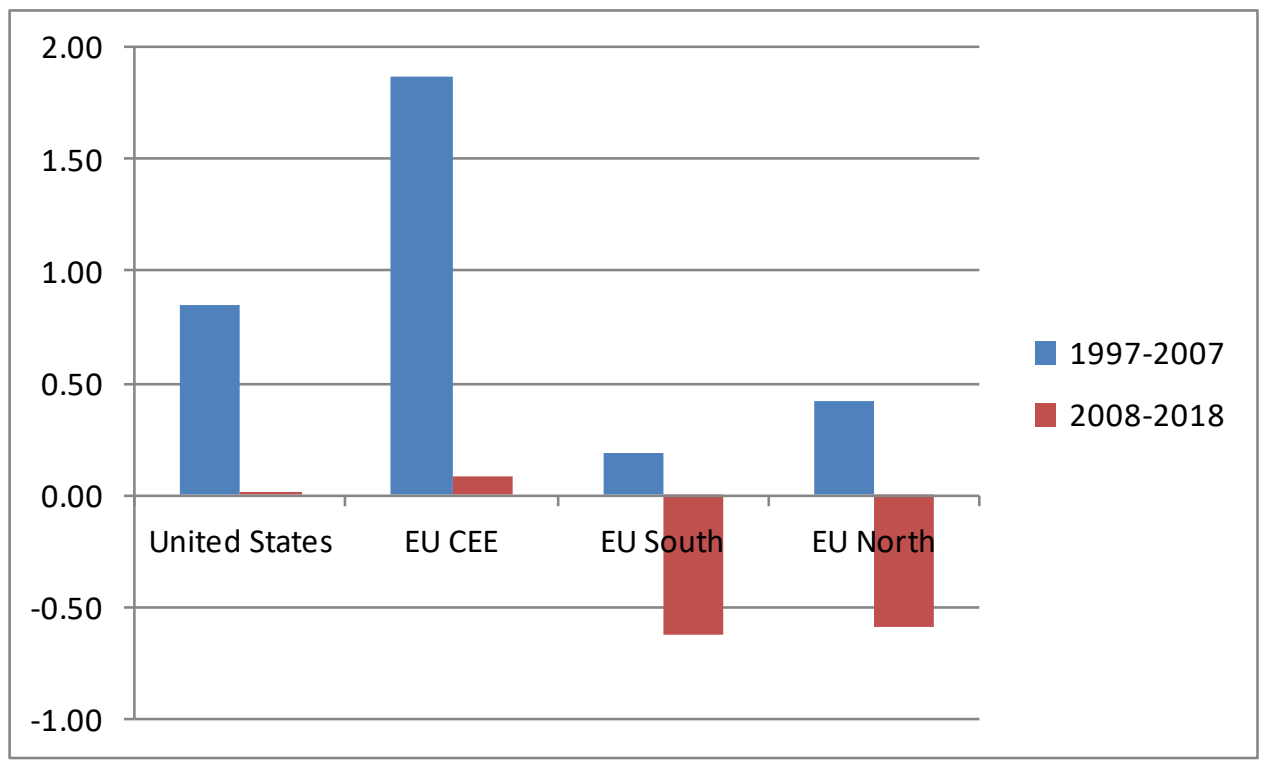

Source: The Conference Board Total Economy Database ${ }^{\mathrm{TM}}$, April 2019 (http://www.conferenceboard.org/data/economydatabase)

Second, the EU productivity decline has been exacerbated by the Eurozone crisis, which led to a deepening of the productivity gap within the region. The Eurozone crisis constitutes a turning point after which the growth rate of labour productivity more than halved, total hours worked declined and GDP growth rates went significantly down (Table 1). In addition, it accentuated regional differences with a declining growth rate in the EU North and EU South and divergence in the EU East (Figure 2).

Table 1: Economic trends in EU28 in two periods (averages)

\begin{tabular}{|c|c|c|}
\hline EU28 & $\begin{array}{c}1997- \\
2007\end{array}$ & $\begin{array}{c}2008- \\
2018\end{array}$ \\
\hline Labour productivity growth & 1.5 & 0.5 \\
\hline Growth of employment (persons engaged) & 1.0 & 0.4 \\
\hline Real GDP growth & 2.7 & 1.0 \\
\hline
\end{tabular}

Source: The Conference Board Total Economy Database ${ }^{\mathrm{TM}}$, April 2019, http://www.conferenceboard.org/data/economydatabase/ 
Figure 2: Growth of Total Factor Productivity in EU28 economies - an average of two periods

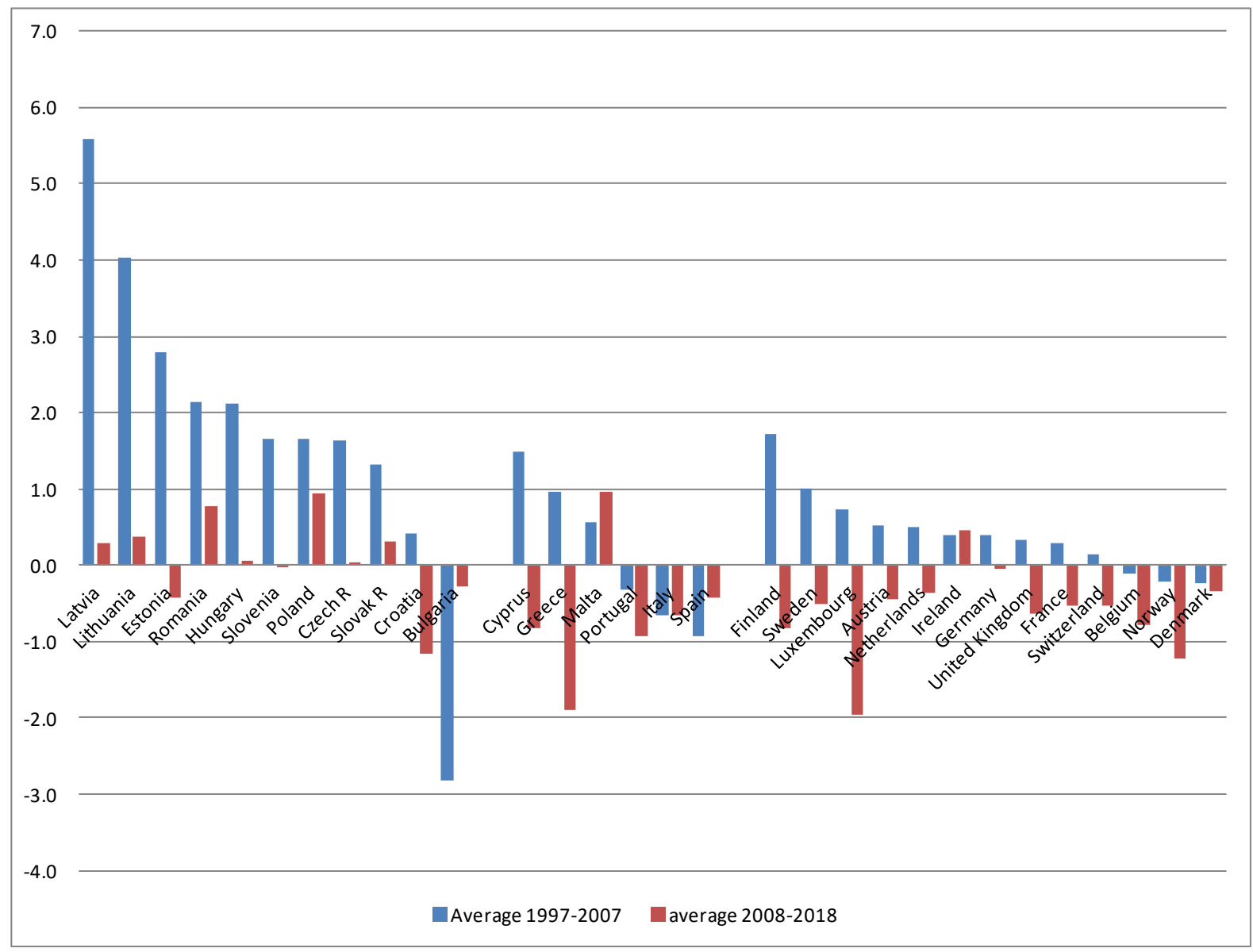

Source: The Conference Board Total Economy Database ${ }^{\mathrm{TM}}$, April 2019, http://www.conferenceboard.org/data/economydatabase/

The prevailing view is that the EU TFP weakness is structural, i.e. it is concentrated in a small set of Information and Communication Technologies (ICT) producing industries. Initially, this weakness has been mainly seen in relation to the US (Timmer et al., 2010). Further research has shown that TFP has been stronger the further the EU countries are away from the frontier, though this effect seems to have been weakening after 1995 (McMorrow et al., 2010). The post-2008 seems to have been the turning point, which demonstrated the breakdown of the EU as a convergence machine and the reemergence of the new South-North divide in Europe (Landesmann, 2015). This may indicate the inadequate model of growth and integration and the possibility that the convergence process will either not proceed or proceed at a much-reduced pace. The last few years show that the declining rate of productivity growth has stopped in most EU countries, but growth rates have not yet returned to pre-2008 levels (Ridao-Cano and Bodewig, 2018).

Therefore, in addition to external structural issue (cf. EU - US productivity gap - see Timmer et al., 2010), we observe the emergence of a second internal structural gap strongly related to deficiencies of the EU South vs. North (Landesmann, 2015). These structural deficiencies are reflected in reduced productivity levels and growth, in a specialisation pattern excessively based on the 'traditional', low, 
and low-medium tech industries, in premature deindustrialisation, declining export shares and, withering international competitiveness' (see Teixeira et al., 2014). This interpretation of EU productivity malaise bodes well with technology gap perspective, which argues that many of the problems that Europe faces today were apparent well before the 2008 crisis struck, as Europe consists of quite a diverse set of countries with different dynamics and technological capabilities (Fagerberg and Verspagen, 2014).

\section{Literature review and research questions}

Our exploration of the determinants of productivity gap in Europe is informed by three types of literature. First, the literature on the determinants of productivity. Second, the literature on technological catch-up and why growth rates differ. Third, the literature on multilevel modelling of growth. As our main focus is the productivity gap, we combine insights from the literature on determinants of productivity gap and from the literature on technological catch-up. Our focus on productivity gap follows from a "Schumpeterian" approach to growth (e.g. Freeman, 1995, 1997; Acemoglu et al., 2006; Aghion and Howitt, 2006). Accordingly, productivity is posited to depend on the rate of innovation and imitation, i.e. on the rate at which frontier technologies are being developed in "technology leaders" and on the rate at which they are transferred to catching-up economies. In other words, a country's or firm's progress differs according to how far it is from the frontier. Countries or firms behind the frontier should grow faster and catch up to the global technological frontier because they benefit from knowledge spillovers from those on the frontier. Examples of the Schumpeterian framework in exploring determinants of TFP at the country level are (Griffith et al. 2004, Nicoletti \& Scarpetta 2003) and at sector level (McMorrow et al., 2010).

We also follow the 'technology gap' approach, postulating that technology and technical knowledge are difficult and costly to transfer (Gershenkron, 1962; Abramovitz, 1986; Maddison, 1991; Fagerberg, 1994). On the one hand, TFP growth for catching up countries relatively close to the frontier is likely to be significantly boosted by technological diffusion from the frontier countries (Savvides and Zachariadis, 2005). On the other hand, the ability of the country to catch up is a function of its absorptive capacity and its innovative capability (Abramovitz, 1986; Castellacci, 2011).

Productivity studies consistently emphasise significant and persistent differences in productivity across countries (Bartelsman et al., 2013) and significant and persistent productivity differences across producers within very narrowly defined industries (Syverson, 2011). However, only a handful of papers have so far tried to explore how differences in cross-country productivity could be linked back to differences in firm-level productivity (for example, Bartelsman et al., 2004, 2009; Dosi et al., 2010). On the contrary, the majority of the literature uses aggregate productivity measures across countries (for example see Castellacci, 2007). But the reliance on aggregate TFP measure is problematic due to its limited theoretical underpinning and practical signification (e.g. Felipe and McCombie, 2014). Indeed, TFP (and productivity more generally) is inherently a micro-concept, which would call for data at more disaggregated levels. And indeed, many papers make use of firm-level data to explore TFP or productivity growth within a sector or industry (Bartelsmann et al., 2004; Faggio et al., 2010). These studies provide insights into what makes a successful firm but have little to say regarding the context in which these firms operate and how contextual variables affect TFP growth. 
Overall, this provides support for a multi-level approach, and indeed, whether the EU productivity gap is structural (de facto sectoral) or firm level based or country-specific or some combination of these multi-level determinants can be answered only within a multi-level framework ${ }^{3}$.

Studies exploiting 'data envelopment analysis' (DEA) follow a similar approach by aiming to attribute the change in labour productivity to different components: technological change, technical efficiency, capital accumulation and human capital (Fare et al., 1994). Within this framework Filippetti and Peyrache $(2015 ; 2017)$ extend the frontier approach developed in Kumar and Russell $(2002)$ : they derive the 'conditional frontier' which is defined as the distance of the country with respect to its maximum achievable level of productivity, to which is added the technology gap component or distance between the conditional frontier of the country and the world frontier. Technology gap in Filippetti and Peyrache $(2015 ; 2017)$ corresponds to the difference between 'Sector/Country' - 'EU Best Sector' while 'conditional inefficiency' corresponds to Firm/Country - Sector/Country gap. We treat the overall productivity gap (Firm - EU Max, i.e. country within a specific sector) as technology gap as for individual firm gap concerning 'conditional (regional/country) frontier' still represent a component of the overall technology gap.

Given the opportunity to explore the determinants of productivity gap in the EU through a multi-level analytical framework, we motivate the selection of different variables in the next sections and in order we explore: the relevance of firm-level determinants (FDI, multi-plant firms, size and age); the relevance of industry determinants at country and EU levels; the relevance of industry-specific direct $R \& D$ and embedded R\&D determinants; finally the relevance of macro, country -determinants, regional factors through EU macro-regions (North, South, East).

\subsection{Firm-level determinants of the productivity gap}

A pervasive empirical finding in the recent literature is the existence of significant and persistent productivity differentials across establishments in the same narrowly defined industry (e.g. at fourdigit level) and these differences dwarf inter-industry differences (Foster et al., 2001). Factors that are used to explain these differences are various and include size, age, location, managerial abilities, innovation capacity, etc., and we try to account for the most important of these factors.

Productivity, size and age of the firm

The relationship between firm size and productivity is known as "Schumpeterian Hypothesis" which underpins the idea that large firms in concentrated markets are more likely to support innovation.

\footnotetext{
${ }^{3}$ For example, Gorodnichenko et al. (2018) show that the firm-level characteristics alone account for 11.2 per cent of the total variation in the log of marginal revenue product of capital and 27.1 per cent of the variation in the log of marginal revenue product of labour. When they allow firm-level characteristics to have different effects by sector or country, they show that firm-level variables explain most of the variation in marginal products within the EU. They conclude that the EU is far from being a single market and that firm-level characteristics coupled with the fixed sector and country features explain most of the observed dispersion. However, treating sector and country level variables only through fixed effects is a potentially limited approach. Given that much of the overall dispersion in marginal products could be attributed to fixed differences among countries or sectors/industries, it is essential to understand what these differences are. We propose to use a multi-level framework to explore firm vs. sector vs. country determinants of the productivity gap.
} 
This hypothesis is justified by the argument that large firms may be able to support a more substantial portfolio of R\&D efforts, increasing the likelihood to develop improved products or processes. However, theoretical research also indicates that a monopolist can have less incentive to innovate. Results on the relationship are inconclusive (for example, Fisher and Peter Temin, 1979; Levin et al., 1985; Soete 1979; Gayle 2003; Acs and Audretscch, 1988; Kinugasa, 1998). Similar to industry concentration, the relationship between size and productivity is not simple. Both industry concentration, as well as size as its essential dimension, are the product of some economic relationships that vary across market environments. In the spirit of the neo-Schumpeterian perspective, the relationship between productivity catch up and industry concentration, size and age may differ across industries depending on technological opportunities and 'appropriability' conditions as well as on distances to the technology frontier. For example, there is evidence that total factor productivity (TFP) in emerging economies tends to increase with firm size (see OECD, 2014, figure 3.12). On the other hand, we would expect that firms' size should not be positively related to TFP when firms are moving towards technology frontier.

The availability of cross country firm-level data enables systematic comparisons of these issues, which suggest that the distributions of productivity and size exhibit a positive correlation, i.e. more productive firms tend to be larger than less productive ones. Bartelsman et al. (2013) show positive covariance between productivity and size across countries, across industries and over time but also show a considerable variation in the strength of the nexus. The latter is the highest in the US manufacturing; it is much lower in the Western European countries and even lower in the economies of Central and Eastern Europe (CEE). They explain these differences by a misallocation hypothesis developed by Hsieh and Klenow, (2009), which suggests that policy-induced distortions affect the allocation of resources across firms as well as the selection of firms producing in each market. However, they also show that the relationship between size and productivity increased substantially in the CEE economies over time, less in Western Europe and, much less in the United States.

Within the EU, there are significant differences in the size of firms. For example, microenterprises account for a significantly larger share of employment and value added in Southern EU than in other EU countries, and they are also much less productive compared to other parts of the EU (Ridao-Cano and Bodeweg, 2018). For example, if the South had the size-mix of other EU15 ('old EU') countries, and its microenterprises had the productivity level of other EU15 countries, its productivity gap with the rest of EU15 would be reduced by 40 per cent (ibid).

It is common to use age as a proxy for the learning curve and accumulated capabilities, age which we also use in this paper. One may expect that on average firms that have been long in existence have old and probably lower quality capital. However, age may also be a proxy for productivity as firms invest in learning by doing, and hence we may also expect that old firms will have higher levels of TFP due to the accumulation of technological capabilities (Jensen et al., 2001). Also, there is new interesting evidence which shows that firm ageing is driving the increase in average firm size and concentration (Hopenhayn et al., 2018).

Therefore, the aggregate outcome of differences in size, age, technology and globalisation are increased dispersion in productivity, whether measured as real value added per worker (labour productivity) or as multi-factor productivity (MFP) (Berlingeri et al., 2017). Most of the increase is 
driven by within-sector across firms' productivity differentials, rather than by cross-sectoral differences (ibid).

\section{MNCs, FDI and multiplant firms and productivity differences}

The productivity gap may be smaller in countries where there is a high share of multiplant and multinational firms, as multinationals are most likely to occur in context with high firm scale economies combined with relatively low plant scale economies (see Navaretti and Venables, 2004) ${ }^{4}$.

Differences in performance between foreign-owned and domestic firms can be substantial (Navaretti and Venables, 2004; Hanousek et al., 2010; Lipsey, 2002; Damijan et al., 2013). For example, foreign presence through FDI, domestic R\&D and firm size are among the most critical factors to enhance TFP in Chinese industries (Liu and Wang, 2003). However, in most cases, performance gaps 'disappear' after controlling for firms and industry characteristics as a structural effect or industry composition effect, not foreign ownership, account for most of the variation (see Bellak, 2004 for a review).

\subsection{Industry level determinants of the productivity gap}

\section{Industry concentration}

Technology and industry structure co-evolve (Nelson, 1995) and hence, levels and dynamics of TFP are intimately related to changes in industry structure. In the literature, industry concentration is typically treated as a result of technological determinants like scale economies, sunk costs, product life cycles, the size of markets, or firm-specific determinants like the organisation structure and accumulated capabilities (learning curve). It is increasingly recognised that industry structure is an endogenous variable, which suggests that the relationship between industry concentration and its various determinants is non-linear. Sutton (1998) shows that technological and demand related factors determine industry concentration through the interplay between exogenous and endogenous sunk costs. Concentrated or dispersed market structure is by itself not a priory promoting or hindering productivity catch-up, i.e. it is industry specific and dependent on the size of the market.

Market structure may affect convergence in productivity through its effects on incentives for firms to engage in R\&D and innovation. The degree of competition - as reflected in different market structures - may affect positively or negatively innovative behaviour and thus, closure of the productivity gap. Cheung et al. (2001) show at the macro level, a significant market structure effect on the persistence of productivity differential. Using data on 11 industries in 17 OECD countries, they show that a concentrated market structure tends to hinder convergence. However, there is not a simple relationship between market structure and innovation (Acemoglu et al., 2006; Aghion et al., 2009). Aghion et al. (2005) show that there is an inverted-U relationship, so only a certain degree of competition positively induces innovative behaviour. On the technology frontier, competition may be conducive to growth but not behind the technology frontier where competition dampens innovation

\footnotetext{
${ }^{4}$ For example, for the US, the rank correlation between the share of FDI employment and the ratio of the firm to plant size is 0.89 across industries (ibid).
} 
by lowering the successful innovators' mark up (ibid). This is consistent with earlier finding from Scherer (1967).

Increased concentration accompanied by increased differences between firms regarding their relative sales, productivity and wages could be interpreted as being due to increased market power. However, an alternative explanation is that this may be due to globalisation and new technologies (cf. 'winner takes all' industry structure) rather than a generalised weakening of competition due to relaxed antitrust rules or regulation (van Reenen 2018). Globalisation and economic integration can also affect the distribution of productivity, but trade may both increase and decrease productivity dispersion. A recent persuasive explanation is that this may be due to increased ageing of companies, i.e. consolidation of industry dynamics (Hopenhayn et al., 2018).

\subsection{Technology gap determinants of the productivity gap}

As our focus is on the determinants of productivity gap, we consider technology gap variables as an autonomous group of factors. Unlike neo-classical growth models (cf. Solow, 1957) which treat technology as a free good, growing at an exogenously given constant rate, the technology gap approach treats technology as the result of cumulative and path dependent activities, which in turn endogenously determine the rate of economic growth (Posner, 1961; Gomulka, 1971; Fagerberg, 1994). Countries operate at different distances to the technology frontier and the ability of countries to catch up with this frontier is closely related to their capacity to imitate frontier innovations and adopt/adapt foreign technologies and knowledge (Fagerberg, 1987). The technological level of a country can be increased only by increased investments in its R\&D, innovation activities as well as by absorption of external technology (Cohen and Levinthal, 1989, 1990). The adoption of imported technologies in lagging behind countries or regions is far from automatic, but it is a crucial dimension in closing the technology gap too. It is also not a costless process (Gerschenkron 1962; Landes 1969; Abramovitz 1986). Technology and technical knowledge are embedded in social conditions of innovative enterprises (Lazonick, 2002a, 2002b), and are not necessarily transferable across different institutional contexts even when there is absorptive capacity available (Basu and Weil 1998; Parente and Prescott, 1994). To sum up, a technology gap can represent a potential for growth but it will only be realised if the country can generate new technological knowledge, absorb existing knowledge and adapt technology (Lall, 1992; Bell and Pavitt, 1993).

In the EU context, Delgado-Rodríguez and Álvarez-Ayuso (2008) analyse labour productivity growth and convergence in $15 \mathrm{EU}$ economies in the period 1980-2001 and find that technological progress tended to contribute to divergence. Filippetti and Peyrache (2017) show that a technology gap reduction, via an increase in endogenous technological capabilities, could be a significant source of growth, particularly for fast converging EU countries. However, being distant from the frontier does not per se guarantee faster rates of labour productivity growth.

In the EU, a cohesion policy has been developed to try and address this technology gap. It provides regions with substantial resources for developing their research and development (R\&D) activity and technological capabilities. Filippetti and Peyrache (2015) show that in lagging behind EU regions, productivity growth is mainly driven by capital accumulation while the technology gap does not play 
a role in driving labour productivity growth and remains stable across regions ${ }^{5}$. Their results suggest that technology gap in the EU remains a source of unused potential productivity growth while cohesion policy seems to be more effective in dealing with physical investment rather than technological capabilities (EU, 2017).

However, the weakness of technology gap based models is the treatment of technology import and its interaction with domestic technology effort. The overwhelming focus is on gaps in technology generation and absorption, but there is a lack of attention to the interaction between technology import and own technology effort. On the other hand, historical evidence shows that there are considerable differences among the economies that have successfully exploited foreign technologies (Mowery and Oxley, 1995). Access to external knowledge is especially important in the context of technology catch-up (Kim, 1997). This can partly be justified by the lack of data on firm-level technology transfer and their links with local domestic registries and partly by the difficulty of modelling this interaction. The important exception in this respect is Chung and Lee (2014). This paper demonstrates that the sequencing between R\&D investments and import of knowledge from abroad matters for successful catching-up, and that the importance of these factors varies in different sectors, and it depends on the forms of imported technology. Against this backdrop, an important contribution of our paper is to account for the interaction between R\&D and imported embedded R\&D as two distinct modes of technology acquisition.

\section{$R \& D$ as a determinant of productivity}

The level and growth of total factor productivity depend on the level and growth of knowledge stock, which is conventionally measured as R\&D (Grilliches, 1979). A standard view is that R\&D differs from other forms of capital investment due to its intangible nature. Knowledge as its core is partially nonrival and non-excludable so that R\&D benefits are not limited to the original investors, but also accrue to competitors, other firms, suppliers, and customers and society at large (Hall et al., 2010). Social returns to R\&D are substantial and exceed private returns by 50 to 100 per cent. Indeed, Sveikauskas (2007) review on the empirical evidence on such rates of return suggests that the private return to $R \& D$ is around 25 per cent, while the social return is around 65 per cent.

At the country level, Kokko et al. (2015) reviewed the literature on the growth effects of R\&D investment with particular reference to the EU. By using meta-analysis, they conclude that the growth effects of R\&D do not differ between US and EU15 or EU27 including high and low R\&D EU spending countries, but the relationship is less significant in the EU than US in all specifications. Their interpretation is that better utilisation of R\&D investments in the US is due to relatively lower private sector investment and weaker public-private sector linkages in the EU ${ }^{6}$. Castellani et al. (2019) show that the EU gap in relation to the US can be explained by not only a lower level of R\&D investment but also by both structural composition and intrinsic effect.

\footnotetext{
${ }^{5}$ Filippetti and Peyrache (2015) show that capital deepening has been the main driver of labour productivity growth for regions in the Eastern EU countries. However, this contradicts evidence within standard growth accounting approach which shows that at least in transition period in the Eastern countries TFP was the main driver of growth (EBRD, 2013; Dobrinsky, R., D. Hesse and R. Traeger, 2006).

${ }^{6}$ However, they do not provide evidence for this latter argument.
} 
Given the dual face of R\&D as a factor of innovative and absorptive (imitative) capacity, R\&D's role is essential in the absorption of foreign R\&D, in either embodied or disembodied form (Cohen and Levinthal, 1989, 1990).

In addition to private and public $R \& D$, there is evidence on the importance of foreign R\&D (see Griffith, Redding and Van Reenen, 2000; Griffith, Redding and Van Reenen, 2004; Xu and Wang, 1999; Eaton and Kortum, 1999, AlAzzawi, 2004). Guellec and Van Pottelsberghe de la Potterie (2004) is probably the only paper that assesses the contribution of private, public and foreign R\&D in one framework. They show that the long-term elasticity of total factor productivity (TFP) for business R\&D is 0.13 , for foreign $R \& D$ is 0.45 , and for the public, $R \& D$ is around 0.17 . These results show quite high returns to foreign R\&D and meagre returns to private R\&D when compared to public R\&D. Their estimates concerning foreign R\&D are in the same order of magnitude as estimates by Coe and Helpman (1995) (0.29) but somewhat higher. This suggests that 'other countries' R\&D matters more than domestic $R \& D$, provided that the country can absorb technology from abroad' (Guellec and Van Pottelsberghe de la Potterie, 2004). However, the issue is that foreign knowledge and R\&D can be embodied in different forms. It can be R\&D embodied in machinery and equipment, in knowledge or patent licences, and they can interact differently with local technology effort (Chung and Lee, 2014). However, in each of the cases, the absorptive capability is a precondition to benefit from foreign technology. We want to build on this critical insight by including variables for "external" R\&D embedded in imported technology, as well as traditional variables for "internal" own R\&D and explore their interaction.

\section{Own R\&D and embodied $R \& D$}

To capture the importance of direct (own) vs. external R\&D, we use data not only on R\&D but also on embedded R\&D. There is extensive research, which shows the limits of direct R\&D in countries behind the technology frontier and their reliance on indirect R\&D or R\&D embodied in imported technology and inputs instead. A broader concept of R\&D includes R\&D embodied in its own and imported inputs and capital goods. R\&D intensity embodied in imported capital goods, and imported inputs are often comparable between developed and semi-developed economies, i.e. they import equally sophisticated equipment and inputs. Hence, the difference in the overall or broader concept of R\&D between countries of different levels of development stems from own R\&D, not from R\&D embodied in imported inputs and capital goods (see Knell, 2008 for evidence). The challenge for catching up countries is how to generate value added on similarly sophisticated equipment and inputs at least regarding R\&D intensity. Their technology effort is focused on how to achieve world levels of productivity by assimilating and adopting foreign technology but in the absence of own R\&D.

Given diverse EU economies, it is plausible that indirect R\&D content dominates in the less developed EU economies (Knell, 2009). When an extended concept of R\&D is taken into account, some countries behind the technology frontier may be de facto more R\&D intensive than technology leaders in specific sectors, as the majority of their technology effort is about effective use and adoption of imported equipment with high-embodied R\&D intensity. Based on this reasoning and evidence, we consider as essential determinants of productivity gap not only own in-house R\&D, but also R\&D embodied in equipment and inputs used in individual sectors as well as their mutual interaction. Technology catching up is essentially about the interaction of endogenous technology effort with foreign technology embodied in different forms (Radosevic, 1999; Filipetti et al., 2016; Chung and Lee, 2014). 
The EU28 is a good example of increasing differences in exposure to foreign technology. Members of the Central European manufacturing core (i.e. five Visegrad economies) have become deeply integrated into European industrial networks while South EU economies are being left out of these networks. There is increasing evidence that this has led to a stronger structural shift towards manufacturing and thus presumably improved technology capability in central Europe, whereas, in South EU, this has accelerated the deindustrialisation process (Stollinger, 2016). However, we should also note that other East European economies (Baltics and South East Europe) have failed to build up a significant export sector through FDI inflows which led to deindustrialisation and very high deficits on their trade accounts (Landesmann, 2015). So, European catching-up economies show differences in exposure to foreign knowledge, linked to different macroeconomic outcomes.

\subsection{Country-level determinants of the productivity gap}

Consistently with the technology-gap theory, the EU28 is composed by countries with different levels of economic and technological development. A critical rationale for the $\mathrm{EU}$ is offering a framework to facilitate technology upgrading in less developed countries and regions by enhancing interaction between their technology effort and the technology of more advanced economies, precisiley via the integration of these economies into the $\mathrm{EU}$ as well as the broader international industrial and technology networks. However, the failure of the EU to renew its role as 'convergence machine' potentially reflects the differences in regional capacities to promote innovation-based growth (Grabner et al., 2017). It could also be a failure to facilitate the interaction between own technology efforts and external sources of technology and knowledge.

In this paper, we consider three EU macro-regions as three different contexts, which explain differences in closing the productivity gap. North, South and East are not geographical notions but a grouping of countries, which share similar technological and developmental features ${ }^{7}$.

\subsection{Summing up: our research issue and hypotheses}

Based on the available data (see next section) and a multi-level approach rooted in Schumpeterian economics, we hypothesise that the EU productivity gap is determined by the interaction between micro, mezzo, macro-regional and technology gap factors. We do not have any a priori view regrading which of these levels should be the most significant but would expect that each level plays a significant role in the productivity gap.

In fact, research on the determinants of productivity shows that firm-level differences are quite important in explaining differences in productivity (Syverson, 2011). On that basis, we would expect that firm-level factors (size, age, ownership, and mutinationality) would be dominant in explaining productivity gaps within the EU. However, contextual or EU-specific factors may affect the relationship between these firm-level factors and productivity gap. Bartelsman et al. (2013) show that the link

\footnotetext{
${ }^{7}$ In North EU we include Germany, France, Belgium, Netherlands, Austria, Ireland, Nordic states and UK, South EU encompasses Italy, Spain, Portugal and Greece while East EU includes all 'new' member states except Croatia, Malta and Cyprus.
} 
between size and productivity is stronger in the EU North than in the EU East. The EU is a technologically and economically diversified global region, and thus, macro-regional differences within Europe should have some relevance in explaining productivity gaps (Gardiner et al., 2004). For example, a recent World Bank study points to differences in labour and financial markets as the primary explanatory factors of the breakdown of 'convergence machine' (Ridao-Cano and Bodewig, 2018). On the other hand, productivity gaps are primarily about technology gaps, which are somehow bigger than economic development gaps.

The EU is the world region with the highest share of intra-regional trade on which basis we should expect that trade and services flows are accompanied by technological knowledge flows (McKinsey 2019). These flows, in conjunction with active policies supporting R\&D and innovation in less developed countries and regions, should moderate the effects of technology gap factors. The interaction of domestic technology efforts, primarily investments in R\&D, coupled with import and assimilation of foreign technology, should influence the closure of productivity gap positively. We already pointed out that foreign technology could be imported as knowledge (e.g. disembodied patent licences) or as embodied R\&D in the form of machinery and equipment. In this paper, we do not capture disembodied imported knowledge but only embodied R\&D through the import of machinery and equipment within the manufacturing sector. We hypothesise that complementarities between investments in machinery and equipment and own R\&D are enhancing absorption and assimilation of foreign technology and thus are essential in closing the productivity gap. A recent paper by Castellani et al. (2019) further supports the relevance of this hypothesis as their evidence suggests that European companies have mainly relied on embodied technological change to foster their levels of productivity.

We analyse these issues at in a multi-level framework, which enables us to use firm, sector and country level variables. We test the hypothesised relationship in the case of four major sectors of different technological levels, which allows us to discuss the coherence of our results across sectors, and describe overall trends.

\section{Data and Methodology}

Our research is based on a sample of 40,263 firms and 143,909 observations within the manufacturing NACE sectors of Computing, Chemicals, Basic Metal and Food (spanning 90 four-digit sectors) located in $15 \mathrm{EU}$ countries in the 2007-2013 period ${ }^{8}$. The source of data for firm-level variables is Bureau van Dijk Amadeus database. These data have been merged with other industry-level data (embodied vs. disembodied R\&D; industry concentration within the domestic and EU market) which have been sourced from World Input-Output Tables and National Statistical offices/Eurostat.

We measure productivity by total factor productivity which is the dominant source of differences in output per worker (Prescott, 1998; Klenow and Rodriguez-Clare, 1997). We prefer to use TFP rather than labour productivity (which is also widely used to analyse productivity) as the latter does not control for capital intensity.

\footnotetext{
${ }^{8}$ Austria, Belgium, Bulgaria, Czech Republic, Germany, Spain, Finland, France, Hungary, Italy, Netherlands, Poland, Romania, Sweden and Slovenia.
} 
We define the technology frontier as the best EU country within a narrowly defined 4-digit sector regarding TFP during the 2007-13 period in our data. We are interested in the determinants of TFP gap or inversely of catching up to the EU industry level technology frontier, i.e. the best EU country within a sector. Our dataset is primarily based on firm-level data, and thus of considerable size. We therefore focus our analyses on firms within each of the four macro-sectors Computing, Chemicals, Basic Metal and Food and explore the variability within and between 4-digits sectors for each one. As mentioned, we are focusing on four manufacturing sectors at different levels of technological sophistication from low to high: Food (NACE 10) representing a low technology industry; Basic Metal (NACE 24), representing a medium-low technology industry; Chemicals (NACE 20), representing a medium-high technology industry; and Computing (NACE 26), representing a high technology industry. We have restricted our inquiry to four sectors by focusing on very detailed examination at four-digit industry level data. However, even at that level, we can observe that the sectoral structure varies considerably across EU economies. EC (2009) shows that five sectors have the most significant impact on other domestic and foreign sectors: motor vehicles, trailers and semi-trailers, primary metals, food products and beverages, office machinery and computers, and chemicals and chemical products. Our four sectors belong to this top five sectors group, and thus, our analysis is macroeconomically relevant.

Our empirical strategy is composed of three steps. Firstly, we follow Foster, Haltiwanger and Syverson (2008) and we estimate TFP as the residual from a 4-digit Cobb-Douglas equation at the EU level in the 2007-2013 period. Second, following Jung and Lee (2010), we compute the EU industry level frontier for the same period by looking at the best-performing country in a specific sector at 4-digit. This allows us to gauge a dual technology catching up measure: on the one hand, we identify the catching up component between a single firm and the average sector in a country; on the other hand, we measure how far the very same firm is from the EU industry level frontier. These two components make up for our total technological gap. Finally, in the third step we test the determinants of total gap (firm - EU maximum) in a multilevel framework, the advantage of which is allowing micro-, mezzoand macro-levels to be modelled simultaneously, addressing the clustering effect (e.g. see G Van Oort et. al, 2012; Goedhuys and Srholec, 2015).

As already stated, our econometric exploration is based on different steps. Let's explore them in order. First, we estimate $\operatorname{TFP}^{9}$ at a 4-digit level as residual of regressions at the firm level for four separate manufacturing sectors as elicited in (1) and (2)

$\ln \left[\right.$ Value Added $\left._{(\text {firm,year }}\right]=\alpha\left[\right.$ Labour $_{(\text {firm }, \text { year })}+\beta\left[\right.$ Fixed Assets $_{\left(\text {firm }_{\text {year }}\right)}+\xi$

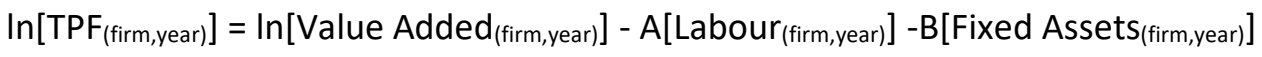

where A and B stand estimated coefficients alpha and beta from equation (1). This detailed level of disaggregation guarantees that industries are quite homogenous entities regarding technical features. Furthermore, calculating TFP at such disaggregated level allows us also to address some common criticism of TFP (see, for example, Felipe and McCombie, 2014).

\footnotetext{
${ }^{9}$ Adopting the Levinson-Petrin (2003) adjustment for endogenous inputs with Ackerberg, Caves, and Frazer. (2015) correction. The resulting residual variable is distributed as a log-normal.
} 
Next, we calculate the total productivity gap as the difference between TFP of the individual firm and the highest level of sector specific TFP (Max EU sector), in three connected steps:

1. We calculate the $75^{\text {th }}$ percentile of the Ln (TFP) for every country, year, 4-digit sector;

2. We calculate the European maximum of that $75^{\text {th }}$ percentile from the previous step: this is done by year and sector, which means that we are looking for a leader (one country) in every year and every 4-digit sector, i.e. the sector-time specific European frontier;

3. After that, we calculate three gaps:

a. Firm - sector: Ln(TFP) for each firm in a particular country / sector/ year minus the $75^{\text {th }}$ percentile from step 1

b. Sector - European Max: $75^{\text {th }}$ percentile from step 1 minus the European max from step 2

c. Firm - European Max: Ln(TFP) of each firm in a particular country/sector/ year minus the maximum from step 2

Namely

Firm_Sector_gap $=\operatorname{Ln}(T F P)_{\text {firm,country,sector,year }}-\operatorname{Ln}(T F P){ }^{75 t h}$ country, year,sector

$\operatorname{Ln}\left(\right.$ TFP) ${ }^{75 \text { th }}$ country, year,sector - [Max $\left.{ }^{\text {country }}{ }_{\text {sector,year }}\right]$

Total Gap firm,country,sector,year $_{\text {L }} \operatorname{Ln}(\text { TFP })_{\text {firm,country,sector,year }}-\left[\right.$ Max $\left.^{\text {country }}{ }_{\text {sector,year }}\right]$

In other words, the total gap is "theoretically" decomposed into two gaps: catching up to country sector level and catching up to EU industry level technology frontier. We exploit equation (5) as our main dependent variable in the regressions' analysis.

Total productivity gap: in order to denote four levels, we use subscript ilkt, i represents firms, I countries, $k$ industrial sectors, and $t$ represents years:

Total Gap firm,country,sector,year $=$ Total Gap i,l,k,t

Given the data hierarchical structure, we employ multilevel modelling. In our model, years represent Level One " $\mathrm{t}$ "; firms represent Level Two "I"; sectors (4-digits) represent Level Three " $k$ ", and countries represent Level Four "I". Failure to account for the nested structure of our data (dependence of observation due to clustering of data) will lead to biased results ${ }^{10}$, especially for coefficients of predictors that are measured at higher levels (Rabe-Hesketh et al. 2005). With this approach, we control for unobserved heterogeneity within different cluster groups (e.g. sector/country). Furthermore, we undertake thorough robustness checks by using a fully-fledged fixed effects model (firms and time fixed effects) vis-à-vis our baseline mixed model.

\subsection{Descriptive statistics}

Table A1 in annex provides the basic descriptive data for four selected sectors. Table A2 gives the list of variables and their description with sources. To minimise potentially adverse effects of extreme

\footnotetext{
${ }^{10}$ For example, firms within an industry-country sample are more alike than a random sample of firms. This is the 'clustering' effect of industry-country groups.
} 
observations, we exclude severe outliers defined as being outside the outer fence, measured by interquartile range multiplied by three. The average gap between a sampled firm and the technology frontier (defined as the best performing sector in the EU) ranges from 25 to $45 \%$. Figure 3 shows that food and chemicals have recorded a small increase in productivity gap over the period. The trend is less clear for computing and metals, but it seems that the 2008 crisis was a turning point for computing, with the gap reducing before 2008 , and increasing afterwards, while the opposite might be true for metals.

\section{Figure 3: Average Gap Firm-Max TFP weighted by shares of countries in the sample}

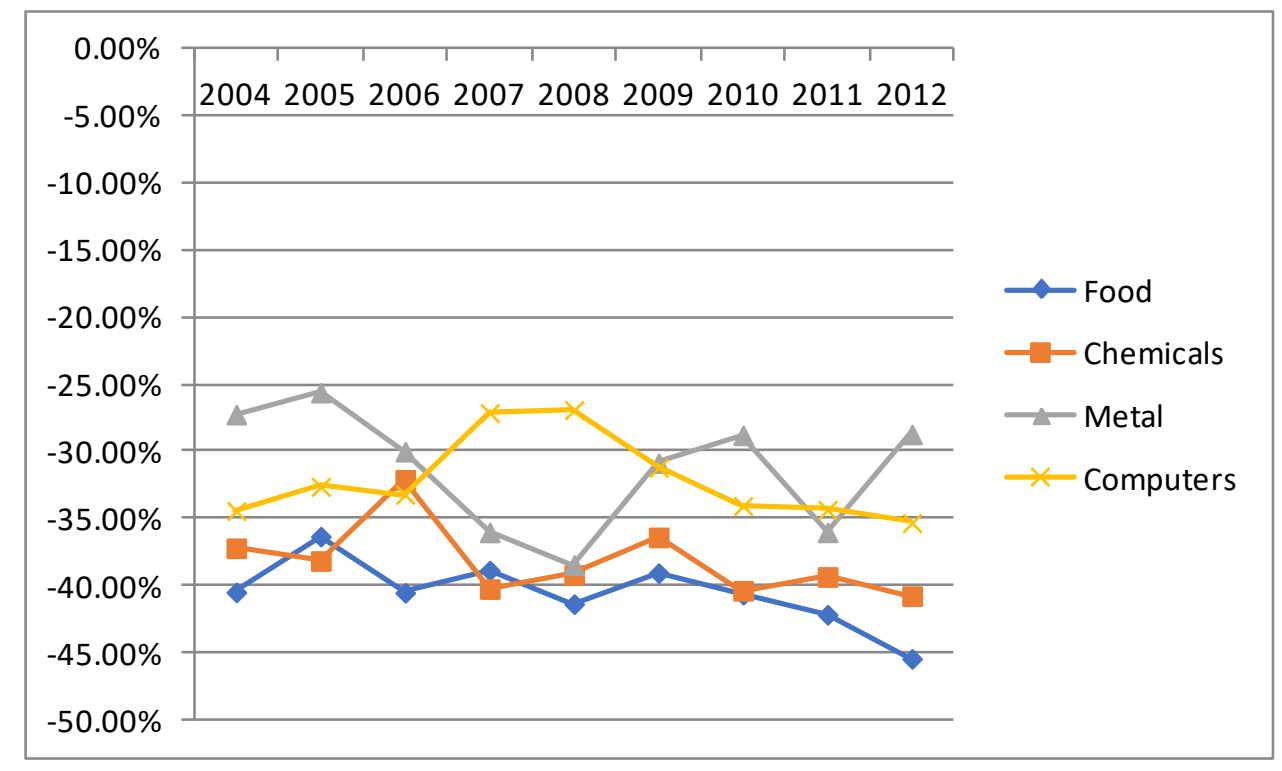

Source: authors' calculation based on BvD Amadeus, see text for step by step computation of the Gap.

We also note that our four sectors are of different R\&D intensity and belong to different technology classes based on innovation patterns (Pavitt, 1984) (figure 4). Therefore, we would expect that the relationships between own and embedded R\&D also differ within each of the four sector. Indeed, this is reflected in the data as R\&D intensity is either higher or significantly higher in chemicals and computers, respectively when compared to embedded R\&D intensity. Also, in both sectors, there is a slight tendency of relatively stronger increase in R\&D intensity and a slight tendency towards lower embedded R\&D intensity. Food and metals have a higher share of embedded R\&D intensity when compared to their R\&D intensity, but this relationship changes after 2008 as own R\&D intensity surpasses embedded R\&D intensity. This may be a reflection of structural changes in industries but also a reflection of increased policy support towards R\&D (or their combination). 
Figure 4: Own R\&D and embedded R\&D intensity in four sectors across EU28

\section{4-13 Sectors' averages for whole countries sample}

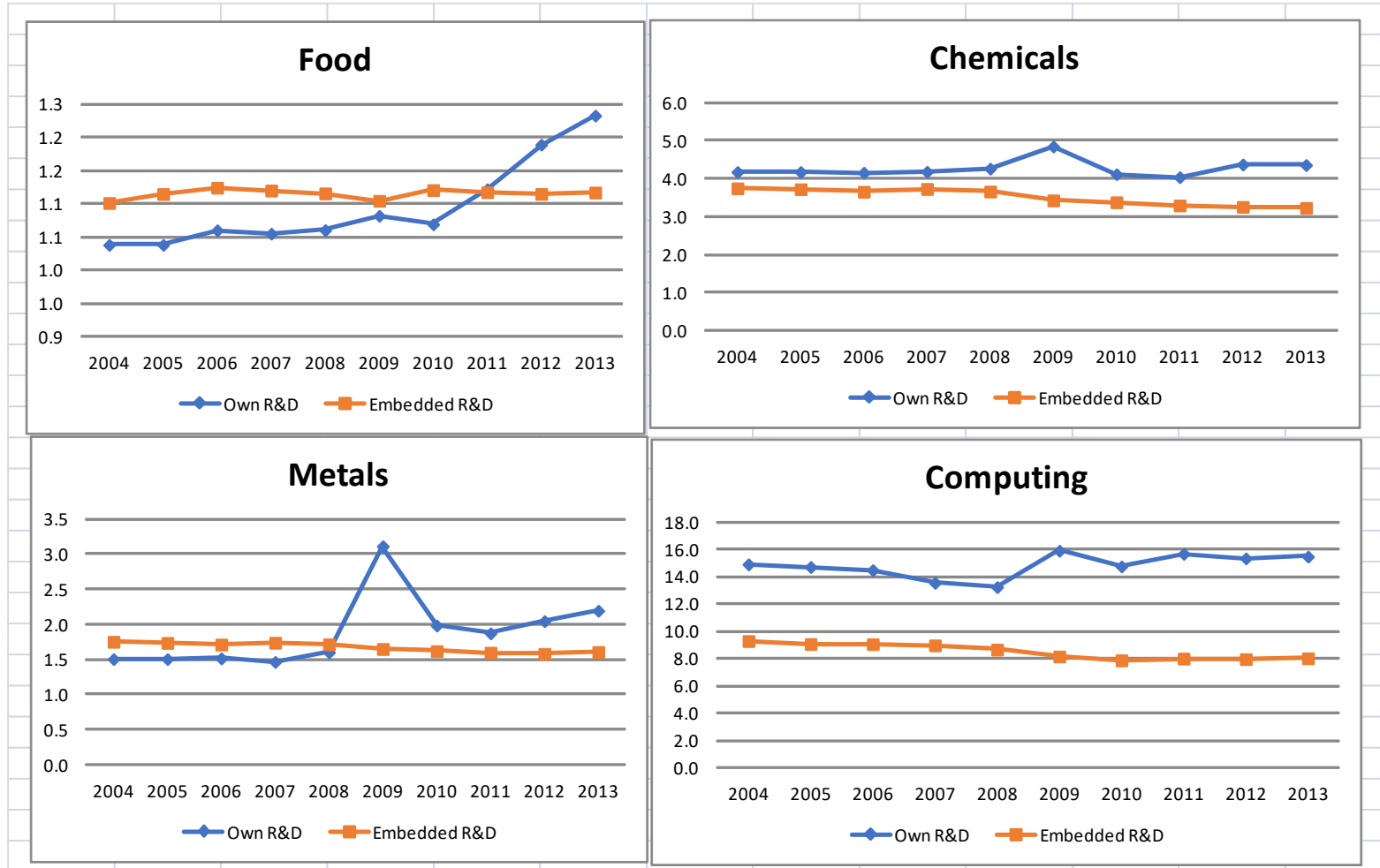

Source: authors' computations based on Eurostat BERD and WIOT (See table A4). Note different vertical scales.

Next in figure 5 we show that in all four sectors in-house R\&D intensity across countries is more dispersed than embedded R\&D intensity. Differences in the sophistication of imported technology are larger in the case of less developed economies and are much less so in developed EU ones. Inversely, the considerable dispersion in own R\&D intensity is due to advanced economies whereas in-house $R \& D$ is quite low in less developed EU economies. Differences in technology gaps and closing of productivity gap may be related to both types of R\&D intensity (own and embedded) but maybe even more to how firms and countries couple their in-house R\&D efforts with imported technology. 
Figure 5: Own R\&D and embedded R\&D intensity in four sectors across EU28 2004-2013 Country-sector averages for the whole time period

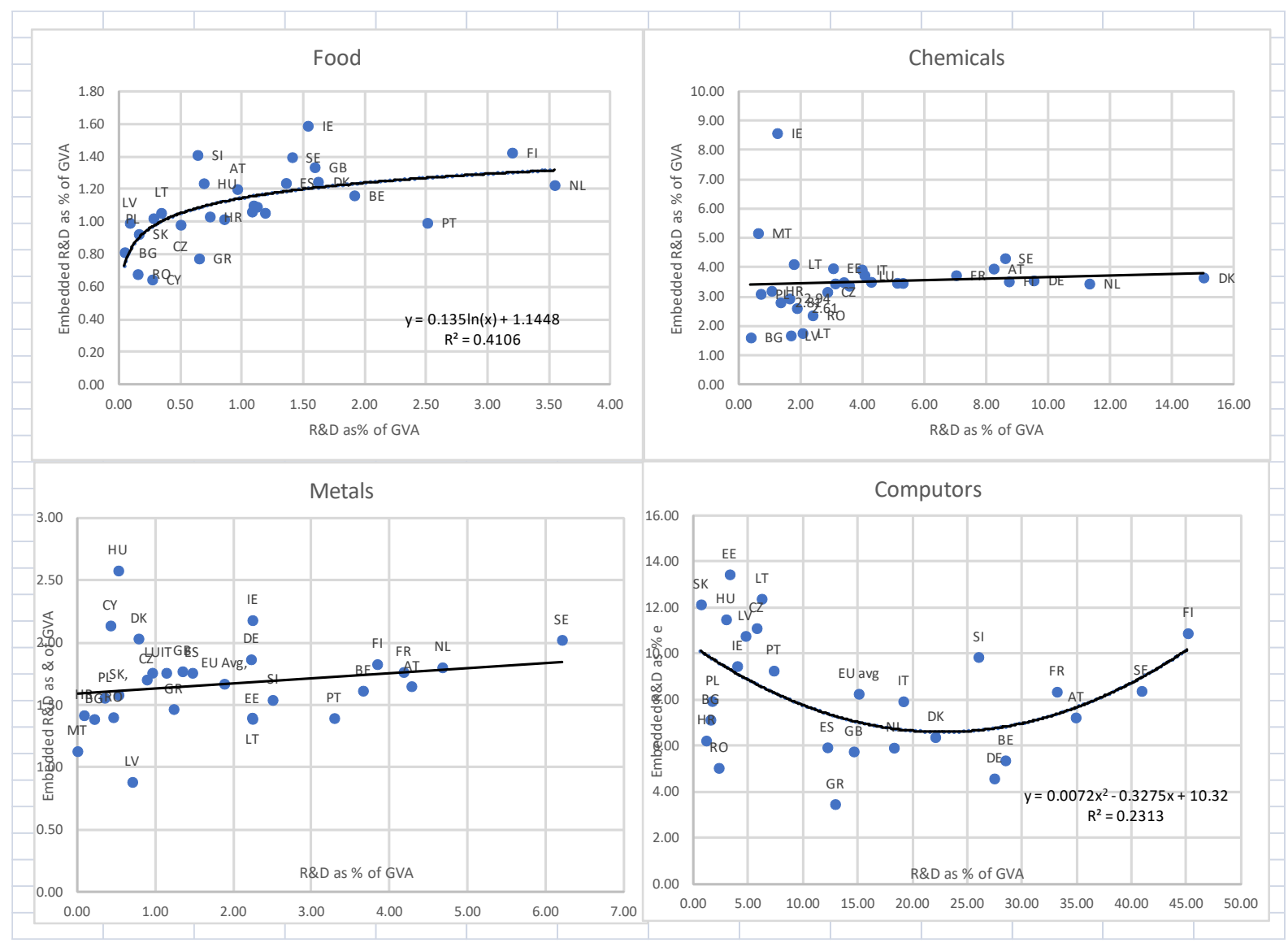

Source: authors' computations based on Eurostat BERD and WIOT (see table A4 for details). Note different vertical and horizontal scales.

\subsection{Empirical Model}

We regress our dependent variable Total GAP on

Tot_GAP $P_{\text {ilkt }}=\alpha+\beta_{1} X_{i l k t}+\beta_{2} X_{l k t}+D_{t}+u_{l}+v_{k l}+\varphi_{i k l}+\varepsilon_{t i k l}$

$X_{\text {ilkt }}$ denotes firm-level time-variant covariates, and $X_{l t k}$ - sector-level covariates (within a country). $\mathrm{D}_{\mathrm{t}}$ time dummies, $u_{l}+v_{k l}+\varphi_{i k l}+\varepsilon_{t i k l}$ is the random part of the equation, where $\mathrm{u}_{l}$ are the country level residuals, $v_{k l}$ - sector within country-level residuals, and $\varphi_{i k l}$ - firm within sector-country level residuals, $\varepsilon_{\text {tikl }}$ shows the completely idiosyncratic errors of years within firms-sectors-countries.

At a firm-level, we control for the number of employees, firm age, fixed capital investment spikes, foreign ownership and the number of subsidiaries overseas. We define investment 'spikes' or 'lumps' as large discrete changes in investment levels in longer periods of low or zero investment (Disney et al., 2018). However, this particular variable generated a large number of outliers. To resolve this issue, we eliminate observations outside the outer fence (defined by inter-quartile range multiplied by three). We also include 4-digit industry concentration within the country and, separately, 2-digit industry concentration at the EU level. Finally, we have both the level of own R\&D (as \% of production) 
and embedded technology (as \% of GVA) ${ }^{11}$ as key "technology gap" explanatory variables. All explanatory variables except age and its square are taken in logs and -with the exception of dummiesare lagged by one year to address potential endogeneity, which may arise because of simultaneity.

\section{Robustness checks}

While a multilevel model takes into account a clustering effect of firm-industry-country sub-groups, the results may be subject to a firm-level unobserved heterogeneity omitted variable bias. Hence, we test the robustness of our results using a fully-fledged fixed effects model as follows:

Tot_GAP $P_{\text {ilkt }}=\alpha+\beta_{1} X_{\text {ilkt }}+\beta_{2} X_{l k t}+D_{t}+\mu_{i}+\varepsilon_{\text {tikl }}$

i.e. the multilevel random part of equation (6) has been replaced by firms FE.

Furthermore, due to missing data, our sample loses its representativeness in terms of the population of EU firms of different sizes across sectors and countries. We address this issue by weighting the remaining firms in the sample in the fixed effects model. We do not apply a weighting in the multilevel setting as this would require to apply weighting at different levels within the random part of the regression which is methodologically non-trivial and would reduce the robustness of our results. On the other hand, applying weights only to a dependent variable would not be justifiable. Hence, we test further robustness of our results using a fixed effects model based on the weighted sample.

\section{Results}

Our baseline regression tests the determinants of the total gap between the firm and EU technology frontier defined as the best sector-country in the EU. In tables 2 to 4, we report results for the nonweighted multilevel (ML) model as well as robustness checks for fixed effects models for both the unweighted and weighted samples.

We interpret our results in three groups of determining factors. First, firm-level specific factors which figure so prominently in the literature on productivity do not seem to be significant in explaining the productivity gap in the EU in the multi-level framework. Foreign ownership and multi-plant nature of firms have insignificant or even negative (food) effects on the closure of the productivity gap (models 1-4, table 2). This suggests that the presence of FDI does not in "itself" contribute to closing the productivity gap, which is primarily determined by technology efforts of domestic firms or interaction between domestic and foreign firms ${ }^{12}$. Insignificant effects of foreign ownership on productivity catching up are de facto not surprising in the light of contradictory and inconclusive evidence on spillover effects of FDI in general (Navaretti and Venables, 2004; Görg and Greenaway, 2003; Moran et al., 2005; Rojec and Knell, 2017) and, the EU in particular (Bruno and Cipollina, 2017). Also, the presence of multiplant firms, which is a usual proxy for export and innovation is either insignificant or negative in the case of the food industry. This probably reflects the much smaller size and degree of internationalisation of firms in the EU periphery when compared to the EU North economies (Altomonte et al., 2013). Size of firms measured by the number of employees also does not affect the

\footnotetext{
${ }^{11}$ Computation of this variable is explained in the appendix A4.

12 It could be channelled via R\&D spillovers, for example.
} 
closure of the productivity gap - with coefficients being industry-specific and either significant but small or insignificant and negative. Given the findings of Bartelsman et al. (2013) in the EU context, this is also a plausible result. Finally, the age of firms is a proxy for accumulated technological capability but also for outdated capital, and is most often insignificant.

Whenever it was discernible from data, we have identified 'spikes' of investments. Investments by firms are characterised by periods of intense investment activity interspersed with periods of much lower investment activity (Doms and Dunne, 1998). As we would expect a positive relationship between investments and productivity at the firm level, it is essential to control for the lumpiness of these investments, which varies considerably across firms. However, we observe that the relationship between investments and subsequent productivity performance can vary widely with respect to the type of effect (positive, negative) (Geylani and Stefanou, 2013; Power, 1998), timing of effects (Sakellaris, 2014), size of firm (Gradzewicz, 2018) and country (Grazzi et al., 2016). Within our multilevel model, this control does not produce significant and consistent results across models. The spike variable is indeed only significant at $5 \%$ level for the food sector, which may reflect the effects of investment and technology embodied in the form of new capital goods. Pavitt (1984)'s taxonomy defines food as a production intensive sector where technology comes from own knowledge inputs but also suppliers of equipment. This suggests that physical investments alone as a determinant of productivity has limited effects unless it is coupled with learning by doing or investments in R\&D. Overall, our inconsistent results across sectors may reflect sector-specific paths of technology upgrading. The uneven nature of physical investments may be less relevant in sectors where technology capability (rather than the vintage of equipment) exert a significant effect on productivity catch up. This result further reinforces the relevance of our econometric model, which shows the importance of quality or sophistication of physical capital as proxied by embedded R\&D intensity and its interaction with its R\&D efforts.

In a nutshell, while firm-level variables and idiosyncratic firm-factors play a major role in explaining productivity differences within industries (Syverson 2011), in our multi-level setting micro-factors (e.g. size, age, multinationality, ownership, etc.) are shown to be insufficient to close the productivity gap with frontier firms.

Regarding industry concentration, our results show that a highly concentrated markets at the countrylevel has adverse effects on productivity gap closure but highly concentrated markets at the EU-level do help closing such gap. Indeed, local oligopolies at the country-level (when most EU-countries are relatively small markets) may affect negatively productivity growth, whereas at the level of the much larger EU market, "economies of scale" may have more of an impact. These results are compatible with the notion that there is no simple one to one relationship between industry structure, innovation and productivity growth (Aghion et al., 2005).

Factors which are consistently positively and significantly correlated to productivity gap are those related to the technology efforts. These factors are own R\&D investments of firms (intramural R\&D expenditures) and R\&D embedded in machinery and equipment. The more countries invest in R\&D; the lower their productivity gap. This result corroborates well with the broad literature on technology gap. In all models, the coefficient for R\&D is positive and significant (models 1-4). Also, in three out of four models (except metal sector) embedded R\&D is positive and significant meaning that firms and countries that import more sophisticated machinery and equipment also have significantly smaller 
productivity gap. However, the interaction between own R\&D and embedded R\&D does not generate positive effects but consistently significantly negative coefficients across three out of four sectors. Coefficients for the interaction variable are high and broadly similar to the coefficients on own and embedded R\&D but of the opposite sign. We consider this a quite important result as it shows that one of the critical determinants that explains closing the productivity gap within the EU is the lack of complementarities between own and embedded R\&D. In the last section, we discuss the policy implications of this crucial econometric result. This is even more important as the four sectors are very diverse regarding R\&D and technology intensity. As far as employment and share in value added are concerned, these are among four of the top five sectors in the EU, and thus, these results are of high macroeconomic relevance.

Productivity divergence within the EU has accentuated the core-periphery dichotomy (Gräbner et al., 2018). The EU is significantly weaker as 'a convergence machine' after 2008, and its increasing territorial polarisation regarding growth and productivity represents a liability to further growth. To check for this feature of EU productivity gap, we use macro-regional dummies which distinguish between EU 'North' and 'South-East' as a periphery. Dummy for 'South-East' is significantly negative for three sectors (except food industry), which shows that being in the periphery represents an additional liability in the closure of the productivity gap ${ }^{13}$. Countries that are either EU South or East are falling behind regarding productivity catch up.

Finally, we control for time year dummies, which are all significant. The high consistency of time dummies estimates suggest that the determinants of productivity gap closure are also driven by macroeconomic shocks across all countries and firms.

Table 2 Multilevel model (non-weighted sample)

\begin{tabular}{|l|c|c|c|c|}
\hline & $(1)$ & $(2)$ & $(3)$ & $(4)$ \\
\hline $\begin{array}{l}\text { Dep: TFP } \\
\text { GAP }\end{array}$ & $\begin{array}{c}\text { NACE 26 } \\
\text { Computing }\end{array}$ & $\begin{array}{c}\text { NACE 20 } \\
\text { Chemicals }\end{array}$ & $\begin{array}{c}\text { NACE 24 } \\
\text { Basic Metal }\end{array}$ & $\begin{array}{c}\text { NACE 10 } \\
\text { Food }\end{array}$ \\
\hline $\begin{array}{l}\text { Ln \# } \\
\text { employees(fir } \\
\text { m)(t-1) }\end{array}$ & $0.00957^{*}$ & -0.00425 & $-0.00793^{+}$ & $0.0334^{* * * *}$ \\
\hline & $(0.00403)$ & $(0.00389)$ & $(0.00468)$ & $(0.00231)$ \\
\hline $\begin{array}{l}\text { Ln \# recorded } \\
\text { Subsidiaries(fi } \\
\text { rm) (t-1) }\end{array}$ & -0.00633 & -0.00674 & 0.00919 & $-0.0586^{* * *}$ \\
\hline & $(0.0109)$ & $(0.00922)$ & $(0.0118)$ & $(0.00724)$ \\
\hline $\begin{array}{l}\text { Dummy } \\
\text { South-East }\end{array}$ & $-0.352^{* * * *}$ & $-0.299^{* * *}$ & $-0.482^{* * *}$ & -0.0323 \\
\hline & $(0.0962)$ & $(0.0696)$ & $(0.0900)$ & $(0.110)$ \\
\hline
\end{tabular}

\footnotetext{
${ }^{13}$ Food industry is one a few sectors where local firms in CEE have been able to compete successfully with foreign producers which may explain insignificant coefficient for this industry.
} 


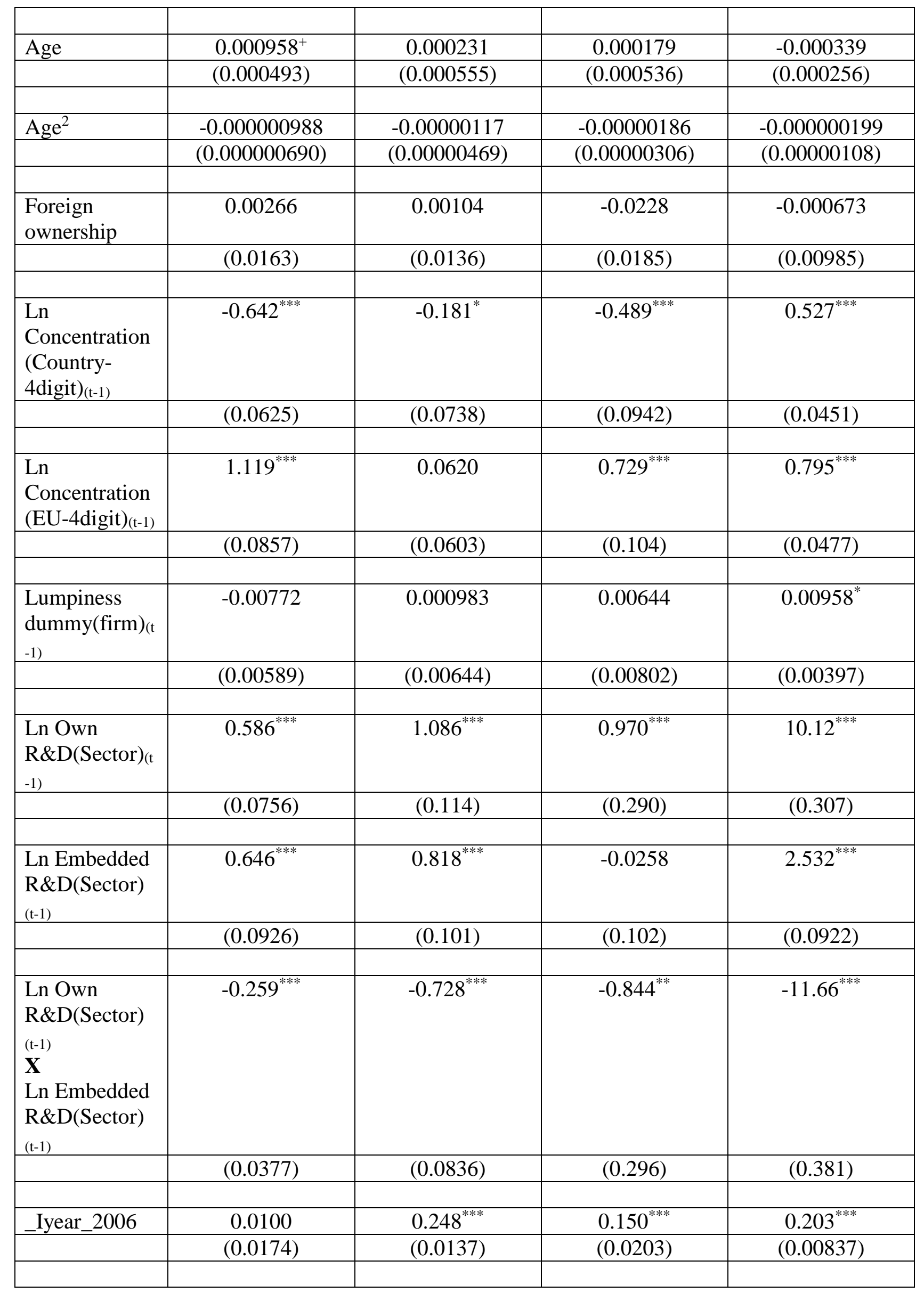




\begin{tabular}{|c|c|c|c|c|}
\hline _Iyear_2007 & $0.207^{* * *}$ & $0.188^{* * *}$ & $0.0614^{* *}$ & $0.368^{* * *}$ \\
\hline & $(0.0168)$ & $(0.0135)$ & $(0.0198)$ & $(0.00796)$ \\
\hline \multirow[t]{2}{*}{ Iyear_2008 } & $0.229^{* * *}$ & $0.151^{* * *}$ & $0.0629^{* * *}$ & $0.349^{* * *}$ \\
\hline & $(0.0162)$ & $(0.0129)$ & $(0.0189)$ & $(0.00730)$ \\
\hline \multirow[t]{2}{*}{ Iyear_2009 } & $0.130^{* * *}$ & $0.207^{\text {*** }}$ & $0.0450^{*}$ & $0.326^{* * *}$ \\
\hline & $(0.0159)$ & $(0.0131)$ & $(0.0185)$ & $(0.00711)$ \\
\hline \multirow{2}{*}{ _Iyear_2010 } & $0.0871^{* * *}$ & $0.122^{* * *}$ & $0.0994^{* * *}$ & $0.243^{* * *}$ \\
\hline & $(0.0129)$ & $(0.0144)$ & $(0.0176)$ & $(0.00684)$ \\
\hline \multirow[t]{2}{*}{ _Iyear_2011 } & $0.0742^{* * *}$ & $0.106^{* * *}$ & $0.0951^{* * *}$ & $0.220^{* * *}$ \\
\hline & $(0.0134)$ & $(0.0132)$ & $(0.0170)$ & $(0.00681)$ \\
\hline \multirow[t]{2}{*}{ _Iyear_2012 } & $0.0733^{* * *}$ & $0.0849^{* * * *}$ & $-0.0362^{*}$ & $0.195^{* * *}$ \\
\hline & $(0.0127)$ & $(0.0127)$ & $(0.0169)$ & $(0.00689)$ \\
\hline \multirow[t]{2}{*}{ _cons } & $-2.186^{* * * *}$ & $-1.807^{* * *}$ & $-0.485^{* * *}$ & $-3.611^{* * * *}$ \\
\hline & $(0.205)$ & $(0.157)$ & $(0.133)$ & $(0.115)$ \\
\hline \multicolumn{5}{|l|}{ lns1_1_1 } \\
\hline \multirow[t]{2}{*}{ _cons } & $-2.090^{* * *}$ & $-2.258^{* * *}$ & $-1.936^{* * *}$ & $-1.610^{* * * *}$ \\
\hline & $(0.368)$ & $(0.253)$ & $(0.231)$ & $(0.206)$ \\
\hline \multicolumn{5}{|l|}{$\operatorname{lns} 2 \_1 \_1$} \\
\hline \multirow[t]{2}{*}{ cons } & $-1.428^{* * *}$ & $-1.766^{* * *}$ & $-1.670^{* * * *}$ & $-1.515^{* * *}$ \\
\hline & $(0.0923)$ & $(0.0762)$ & $(0.0863)$ & $(0.0559)$ \\
\hline \multicolumn{5}{|l|}{$\operatorname{lns} 3$ _1_1 } \\
\hline \multirow[t]{2}{*}{ cons } & $-0.951^{* * *}$ & $-0.993^{* * *}$ & $-1.083^{* * *}$ & $-0.927^{* * *}$ \\
\hline & $(0.0116)$ & $(0.0110)$ & $(0.0150)$ & $(0.00608)$ \\
\hline \multicolumn{5}{|l|}{ lnsig_e } \\
\hline \multirow[t]{2}{*}{ cons } & $-1.239^{* * * *}$ & $-1.255^{* * * *}$ & $-1.105^{* * *}$ & $-1.116^{* * *}$ \\
\hline & $(0.00594)$ & $(0.00524)$ & $(0.00636)$ & $(0.00294)$ \\
\hline \multicolumn{5}{|l|}{$R^{2}$} \\
\hline$N$ & 20479 & 25147 & 16617 & 81666 \\
\hline
\end{tabular}

Clustered Standard errors in parentheses ${ }^{+} p<0.10,{ }^{*} p<0.05,{ }^{* * *} p<0.01,{ }^{* * *} p<0.001$.

A positive coefficient sign entails a reduction of the gap.

Finally, we check further the robustness of these results by considering a FE model equivalent to equation (7), with a non-weighted (table 3) and weighted sample (table 4). We assume that these firm-level time-invariant characteristics are also unique to the country, and we expect that by removing the effect of those time-invariant characteristics, we can assess the determinants on the productivity gap without omitted variable bias by unobserved heterogeneity. 
Table 3 Fixed Effects Model (non-weighted sample)

\begin{tabular}{|c|c|c|c|c|}
\hline & (1) & (2) & (3) & (4) \\
\hline $\begin{array}{l}\text { Dep: TFP } \\
\text { GAP }\end{array}$ & $\begin{array}{c}\text { NACE } 26 \\
\text { Computing }\end{array}$ & $\begin{array}{l}\text { NACE } 20 \\
\text { Chemicals }\end{array}$ & $\begin{array}{c}\text { NACE } 24 \\
\text { Basic Metal }\end{array}$ & $\begin{array}{l}\text { NACE } 10 \\
\text { Food }\end{array}$ \\
\hline \multirow[t]{2}{*}{$\begin{array}{c}\operatorname{Ln} \# \\
\text { employees(fir } \\
m)_{(\mathrm{t}-1)} \\
\end{array}$} & $0.0187^{+}$ & 0.0201 & -0.0136 & $0.0417^{* * *}$ \\
\hline & $(0.0108)$ & $(0.0146)$ & $(0.0159)$ & $(0.00699)$ \\
\hline \multirow[t]{2}{*}{ Age } & $0.00715^{*}$ & $-0.0413^{* * * *}$ & $-0.0284^{* * *}$ & $-0.0363^{* * *}$ \\
\hline & $(0.00364)$ & $(0.00308)$ & $(0.00420)$ & $(0.00200)$ \\
\hline \multirow[t]{2}{*}{$\mathrm{Age}^{2}$} & $-0.0000550^{+}$ & $0.0000633^{*}$ & $0.000116^{* *}$ & $0.000137^{* * *}$ \\
\hline & $(0.0000281)$ & $(0.0000282)$ & $(0.0000402)$ & $(0.0000221)$ \\
\hline \multirow{2}{*}{$\begin{array}{c}\text { Ln } \\
\text { Concentration } \\
\text { (Country- } \\
\text { 4digit })_{(\mathrm{t}-1)} \\
\end{array}$} & $-0.640^{* * *}$ & $-0.225^{*}$ & $-0.300^{* *}$ & $0.762^{* * * *}$ \\
\hline & $(0.104)$ & $(0.0903)$ & $(0.114)$ & $(0.0549)$ \\
\hline \multirow{3}{*}{$\begin{array}{l}\text { Ln } \\
\text { Concentration } \\
{\text { (EU-4digit })_{(\mathrm{t}-1)}}\end{array}$} & $1.487^{* * *}$ & -0.0459 & $1.007^{* * *}$ & $0832^{* * * *}$ \\
\hline & & & & \\
\hline & $(0.137)$ & $(0.0697)$ & $(0.130)$ & $(0.0602)$ \\
\hline \multirow{2}{*}{$\begin{array}{c}\text { Lumpiness } \\
\text { dummy(firm) })_{(\mathrm{t}} \\
-1)\end{array}$} & -0.00981 & 0.00117 & 0.00962 & $0.00806^{+}$ \\
\hline & $(0.00663)$ & $(0.00700)$ & $(0.00895)$ & $(0.00460)$ \\
\hline \multirow{2}{*}{$\begin{array}{c}\text { Ln Own } \\
\text { R\&D }(\text { Sector })_{(\mathrm{t}} \\
-1)\end{array}$} & $0.641^{* * *}$ & $1.063^{* * *}$ & $0.971^{* * *}$ & $10.29^{* * *}$ \\
\hline & $(0.113)$ & $(0.172)$ & $(0.280)$ & $(0.411)$ \\
\hline \multirow{2}{*}{$\begin{array}{c}\text { Ln Embedded } \\
\text { R\&D(Sector) } \\
\text { (t-1) }\end{array}$} & $0.803^{* * *}$ & $0.812^{* * *}$ & -0.0449 & $2.485^{* * *}$ \\
\hline & $(0138)$ & $(0136)$ & $(0,03)$ & $(0$ 120) \\
\hline & & & & \\
\hline $\begin{array}{c}\text { Ln Own } \\
\text { R\&D(Sector) }\end{array}$ & $-0.323^{* * *}$ & $-0.727^{* * * *}$ & $-0.891^{* *}$ & $-11.88^{* * * *}$ \\
\hline$\stackrel{(\mathrm{t}-1)}{\mathbf{X}}$ & & & & \\
\hline Ln Embedded & & & & \\
\hline $\mathrm{R} \& \mathrm{D}$ (Sector) & & & & \\
\hline$(\mathrm{t}-1)$ & & & & \\
\hline
\end{tabular}




\begin{tabular}{|c|c|c|c|c|}
\hline & $(0.0556)$ & $(0.114)$ & $(0.286)$ & $(0.504)$ \\
\hline \multirow[t]{2}{*}{ 2007.year } & $0.190^{* * *}$ & $-0.0245^{\text {** }}$ & $-0.0660^{* * * *}$ & $0.192^{* * *}$ \\
\hline & $(0.0130)$ & $(0.00925)$ & $(0.0129)$ & $(0.00745)$ \\
\hline \multirow[t]{2}{*}{ 2008.year } & $0.213^{* * *}$ & $-0.0270^{* *}$ & $-0.0423^{* * *}$ & $0.204^{* * * *}$ \\
\hline & $(0.0122)$ & $(0.00882)$ & $(0.0126)$ & $(0.00632)$ \\
\hline \multirow[t]{2}{*}{ 2009.year } & $0.110^{* * *}$ & $0.0669^{* * *}$ & $-0.0374^{* *}$ & $0.212^{* * *}$ \\
\hline & $(0.0118)$ & $(0.00990)$ & $(0.0131)$ & $(0.00623)$ \\
\hline \multirow[t]{2}{*}{ 2010.year } & $0.0822^{* * *}$ & $0.0220^{+}$ & $0.0481^{* *}$ & $0.156^{* * *}$ \\
\hline & $(0.0109)$ & $(0.0131)$ & $(0.0148)$ & $(0.00644)$ \\
\hline \multirow[t]{2}{*}{ 2011.year } & $0.0645^{\text {**** }}$ & $0.0448^{\text {**** }}$ & $0.0588^{\text {**** }}$ & $0.166^{* * *}$ \\
\hline & $(0.0114)$ & $(0.0133)$ & $(0.0150)$ & $(0.00714)$ \\
\hline \multirow[t]{2}{*}{ 2012.year } & $0.0629^{* * * *}$ & $0.0599^{* * *}$ & $-0.0528^{* * *}$ & $0.171^{* * *}$ \\
\hline & $(0.0122)$ & $(0.0148)$ & $(0.0179)$ & $(0.00824)$ \\
\hline \multirow[t]{2}{*}{ _cons } & $-2.762^{* * *}$ & $-0.933^{* * *}$ & -0.160 & $-2.804^{* * *}$ \\
\hline & $(0.286)$ & $(0.216)$ & $(0.162)$ & $(0.103)$ \\
\hline$\overline{R^{2}}$ & 0.801 & 0.777 & 0.730 & 0.783 \\
\hline$N$ & 20479 & 25147 & 16617 & 81666 \\
\hline
\end{tabular}

Clustered Standard errors in parentheses ${ }^{+} p<0.10,{ }^{*} p<0.05,{ }^{* *} p<0.01,{ }^{* * *} p<0.001$. A positive coefficient sign entails a reduction of the gap.

Table 3 estimates equation (7) on the same unweighted sample of the Multilevel Analysis presented in Table 2. The results are broadly consistent. Size of the firm helps to reduce the gap in the food sector. Age tends to exert a negative (but quadratic, inverted $U$ shape) effect on the gap, except for computing. Market concentration at the country level is, as before, negatively correlated to the productivity gap while at the EU-level, effects are positive (except of metal). However, the most striking result concerns the technology effort variables, which remain of the same sign and size on all models respectively (including non-significant coefficient for Basic Metal embedded technology). These results confirm technology factors as dominant explanatory factors within the EU productivity gap for three out of four sectors.

Table 4 reports a last robustness check using EU wide firms' population sample-weights, and suggests that the importance of R\&D, embedded R\&D and their interaction may be country-specific. However, it also points that the relationships and importance of R\&D and embedded R\&D vary across our four sectors. While in three sectors (computers, chemicals and food), this relationship is entirely consistent, for metals, specific features are revealed. Indeed, Basic metals industry (NACE 24) is characterised by a continuous process of innovation but the required investment is seldom undertaken as it tend to be large and associated with delayed returns. For example, in the steel industry, technologies in use are the result of the investments, experience and knowledge accumulated over many years and decades. To sum up, embedded R\&D is essential in basic metals but its effects on productivity only appears in 
the long term, at the same time, learning by doing and progressive improvements in existing technology can be important, but they are not necessarily reflected in R\&D figures (Silva, 2015).

Table 4: Fixed Effects Model (weighted sample)

\begin{tabular}{|c|c|c|c|c|}
\hline & $(1)$ & (2) & (3) & (4) \\
\hline $\begin{array}{l}\text { Dep: TFP } \\
\text { GAP }\end{array}$ & $\begin{array}{l}\text { NACE } 26 \\
\text { Computing }\end{array}$ & $\begin{array}{l}\text { NACE } 20 \\
\text { Chemicals }\end{array}$ & $\begin{array}{c}\text { NACE } 24 \\
\text { Basic Metal }\end{array}$ & $\begin{array}{l}\text { NACE } 10 \\
\text { Food }\end{array}$ \\
\hline \multirow[t]{2}{*}{$\begin{array}{c}\operatorname{Ln} \# \\
\text { employees(fir } \\
m)_{(\mathrm{t}-1)} \\
\end{array}$} & 0.0168 & 0.00669 & -0.0193 & $0.0233^{* *}$ \\
\hline & $(0.0104)$ & $(0.0134)$ & $(0.0201)$ & $(0.00745)$ \\
\hline \multirow[t]{2}{*}{ Age(firm) } & 0.00338 & $-0.0392^{* * * *}$ & $-0.0241^{* * * *}$ & $-0.0361^{* * *}$ \\
\hline & $(0.00362)$ & $(0.00310)$ & $(0.00431)$ & $(0.00228)$ \\
\hline \multirow[t]{2}{*}{ Age $(\text { firm })^{2}$} & $-0.0000521^{*}$ & 0.0000497 & $0.000107^{*}$ & $0.000148^{* * * *}$ \\
\hline & $(0.0000255)$ & $(0.0000303)$ & $(0.0000444)$ & $(0.0000243)$ \\
\hline \multirow{2}{*}{$\begin{array}{c}\text { Ln } \\
\text { Concentration } \\
(\text { Country- } \\
\text { 4digit })_{(\mathrm{t}-1)} \\
\end{array}$} & $-0.552^{* * *}$ & $-0.485^{* * *}$ & $-0.870^{* * * *}$ & $0.604^{* * * *}$ \\
\hline & $(0.0975)$ & $(0.0917)$ & $(0.137)$ & $(0.0592)$ \\
\hline \multirow{2}{*}{$\begin{array}{l}\text { Ln } \\
\text { Concentration } \\
{\text { (EU-4digit })_{(\mathrm{t}-1)}}\end{array}$} & $1.468^{* * *}$ & -0.0112 & $1.181^{* * * *}$ & $0.957^{* * *}$ \\
\hline & $(0.136)$ & $(0.0655)$ & $(0.147)$ & $(0.0622)$ \\
\hline \multirow{2}{*}{$\begin{array}{c}\text { Lumpiness } \\
\text { dummy(firm) }(\mathrm{t} \\
-1)\end{array}$} & -0.00380 & -0.00719 & 0.00829 & -0.00206 \\
\hline & $(0.00654)$ & $(0.00703)$ & $(0.00979)$ & $(0.00453)$ \\
\hline \multirow{2}{*}{$\begin{array}{c}\text { Ln Own } \\
\text { R\&D }(\text { Sector })_{(\mathrm{t}} \\
-1)\end{array}$} & $0.663^{* * *}$ & $0.780^{* * * *}$ & 0.256 & $10.62^{* * * *}$ \\
\hline & $(0.120)$ & $(0.163)$ & $(0.315)$ & $(0.468)$ \\
\hline \multirow{3}{*}{$\begin{array}{c}\text { Ln Embedded } \\
\text { R\&D(Sector) } \\
(\mathrm{t}-1)\end{array}$} & $0.792^{* * * *}$ & $0.605^{* * *}$ & $-0.214^{+}$ & $2.669^{* * *}$ \\
\hline & & & & \\
\hline & $(0.154)$ & $(0.137)$ & $(0.115)$ & $(0.142)$ \\
\hline $\begin{array}{c}\text { Ln Own } \\
\text { R\&D(Sector) }\end{array}$ & $-0.347^{* * *}$ & $-0.565^{* * * *}$ & -0.301 & $-13.40^{* * * *}$ \\
\hline
\end{tabular}




\begin{tabular}{|c|c|c|c|c|}
\hline $\begin{array}{c}(\mathrm{t}-1) \\
\mathbf{X} \\
\text { Ln Embedded } \\
\text { R\&D(Sector) } \\
(\mathrm{t}-1)\end{array}$ & & & & \\
\hline & $(0.0612)$ & $(0.114)$ & $(0.313)$ & $(0.611)$ \\
\hline & & & & $-2.595^{* * *}$ \\
\hline Cons & $-2.588^{* * *}$ & $-0.443^{*}$ & 0.261 & $(0.120)$ \\
\hline$R^{2}$ & $(0.320)$ & $(0.218)$ & $(0.196)$ & 0.794 \\
\hline$N$ & 0.799 & 0.777 & 0.702 & 81666 \\
\hline
\end{tabular}

Clustered Standard errors in parentheses ${ }^{+} p<0.10,{ }^{*} p<0.05,{ }^{* *} p<0.01,{ }^{* * *} p<0.001$, Full set of Firm level and time level fixed effects accounted for. A positive coefficient sign entails a reduction of the gap.

Summing up, there is a positive contribution of own R\&D for all four sectors and embedded R\&D for three out of four sectors (except metals), and our results are entirely consistent between $\mathrm{ML}$ (unweighted), fixed effects (unweighted) and fixed effects (weighted) models. Furthermore, our results regarding the interaction between $R \& D$ and embedded $R \& D$ are negative and significant, across our different models (except for the metals sector). As explained above, this latter result for metal may reflect the specific nature of technology cycles in this industry.

\subsection{Exploring the relationship between own and embedded R\&D}

We have found a positive - or marginally insignificant and negative in the case of metal - association between embedded R\&D and closing the gap, and a positive and significant association between level of investment in own R\&D and closing the gap for all the four sectors. We also noted that the interaction between own and embedded R\&D was found to have a negative sign for all sectors. This result is particularly important as it suggests that in-house R\&D and embedded R\&D are substitutes, rather than complements. This may suggest that there are mismatches between two types of investments regarding timing, significance and possibly forms of knowledge (Chung and Lee, 2014).

We provide below a set of graphical representations, where for each sector, in turn, we show: the marginal effect of own R\&D on TFP gap closure conditional on embedded technology (graphs labelled as (a)); the marginal effect of embedded technology on TFP gap closure conditional on own R\&D (graphs labelled as (b)). For this exercise we exploit the results of the FE weighted model, which we regard as the toughest robustness check. These graphs thus represent (a) the relative effect of own $R \& D$ as embedded technology increases, taking into consideration their negative interactions, and (b) the relative effect of embedded technology as own R\&D increases, again taking into consideration their negative interactions. We note that these effects are static effects. We also need to remind the reader that own, and embedded R\&D are measured at sub-sectoral 2-digit level rather than firm leve ${ }^{14}$. The estimated coefficients thus reflect whether firms operating in sub-sectors with more investment in R\&D given the level of embedded R\&D are further away from the overall sector frontier (and vice versa). In all cases, the marginal effects are shown to be downward sloping, consistently with

\footnotetext{
${ }^{14}$ This might also mitigate endogeneity concerns.
} 
the negative sign we reported for the interaction terms within the regressions of table 4 (FE weighted). This indicates that in all sectors, firms operating in subsectors with a high level of both investment in own R\&D and embedded R\&D are less and less likely to be associated with closing the gap. We now comment on each sector one by one.

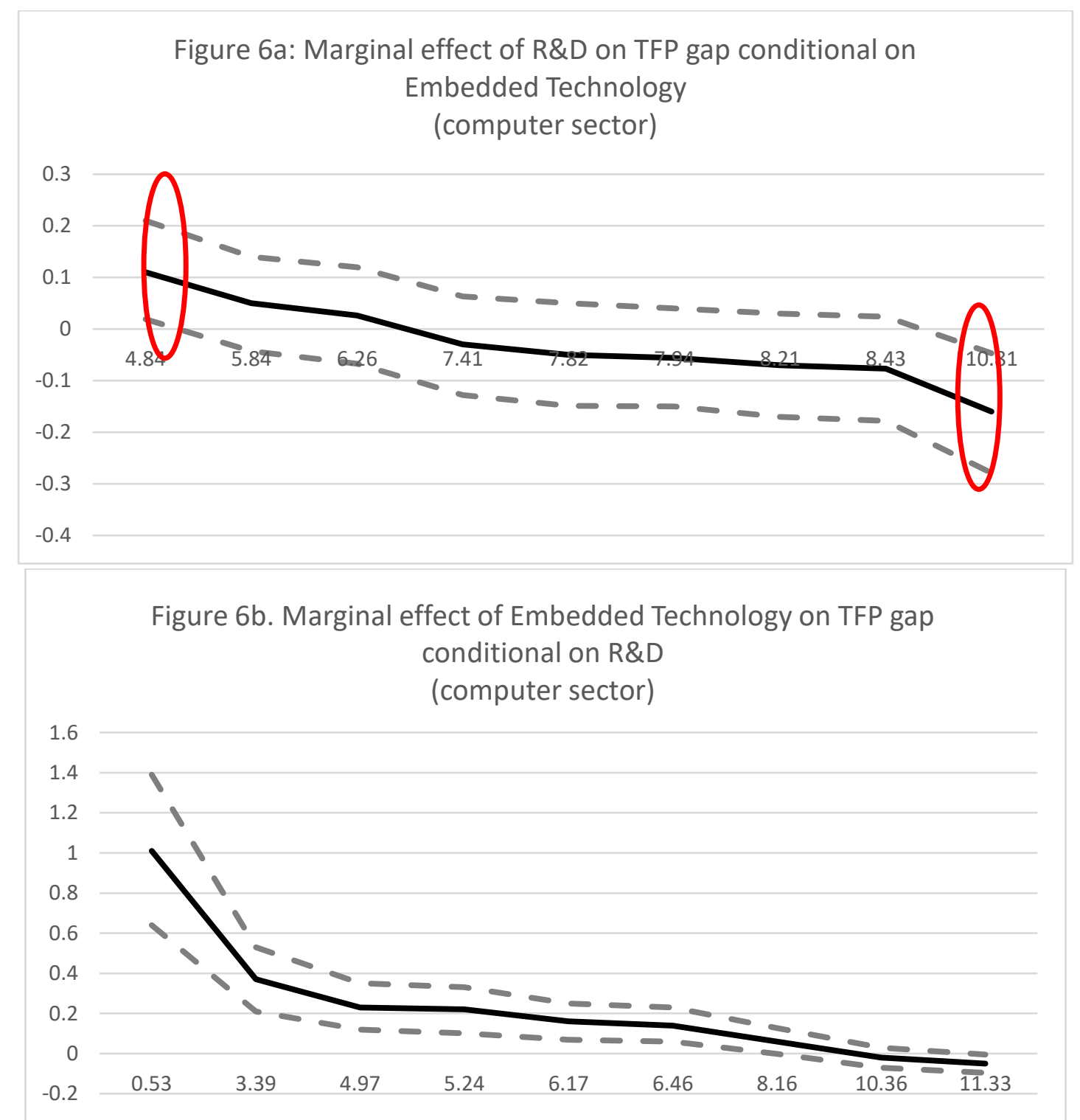

Source: Authors calculations based on regressions results from the FE weighted model of table 4

\section{Computers}

Focusing on computer sector first, on the one hand the marginal effects of sub-sectoral R\&D on TFP gap conditional on embedded technology is positive and significant at a very low level of embedded technology, but it follows a gentle negative slope until it reaches a negative and significant value for relatively high levels of embedded technology. However, for most values of embedded technology (between these two extreme points) and the values most relevant to our sample, the marginal effect is, in fact, insignificant. Hence, in the computing sector overall, the firms that operate in sub-sectors with a relatively low level of embedded technology are closer to the frontier. For all other sub-sectors, greater levels of own R\&D are not associated with a reduction in the gap. Results in table 4, column 1 (FE weighted model) shows that R\&D on its own does contribute to improvement in productivity, and 
especially in sub-sectors, where embedded R\&D is low (figure 6a). These are most likely subsectors where catching up is R\&D driven and does not depend on sophisticated equipment.

On the other hand, focusing on the marginal effect of embedded technology on the TFP gap conditional on sub-sectoral R\&D, the marginal effects are significant and positive but decreasing, to reach a non-significant level at very high values of own R\&D. Firms tend to be closer to the overall sector frontier if they operate in sub-sectors with some investment in embedded technology, but the return to embedded technology decreases with own R\&D intensity. In sub-sectors with greater reliance on $R \& D$, investment in embedded technology explains less and less of the gap closure. Conversely, embedded technology is more likely to contribute to closing the gap in sub-sectors with lower R\&D intensity.

Overall, this suggests some heterogeneity in the computer sector overall, with some sub-sectors with very low levels of embedded technology being able to close the gap thanks to investment in own R\&D, and a larger number of more homogenous producers which are focusing on adapting existing technologies and for whom R\&D might be required in relative small levels, but for whom it is embedded technology that contributes to closure of the TFP gap.

\section{Chemicals}

A similar conclusion can be reached for chemicals, as the marginal effect of R\&D on TFP gap conditional on embedded technology is positive and significant at a low level of embedded technology, but insignificant for higher levels of R\&D intensity. Thus, in sub-sectors, where embedded technology is less R\&D intensive, investment in R\&D is associated with a closing of the gap. Firms operating in sub-sectors with relatively high levels of embedded technology, greater R\&D intensity is not associated with a reduction of the gap. Investment in R\&D lead to a reduced gap, but their interaction with embedded R\&D does not necessarily lead to gap reduction. On the other hand, the marginal effect of embedded technology on the TFP gap conditional on R\&D is positive and significant for most of the values depicted in figure $7 \mathrm{~b}$. Thus, for any level of R\&D investment, investment in embedded technology leads firms closer to the frontier, suggesting a particular relationship between $R \& D$ and embedded R\&D investments.

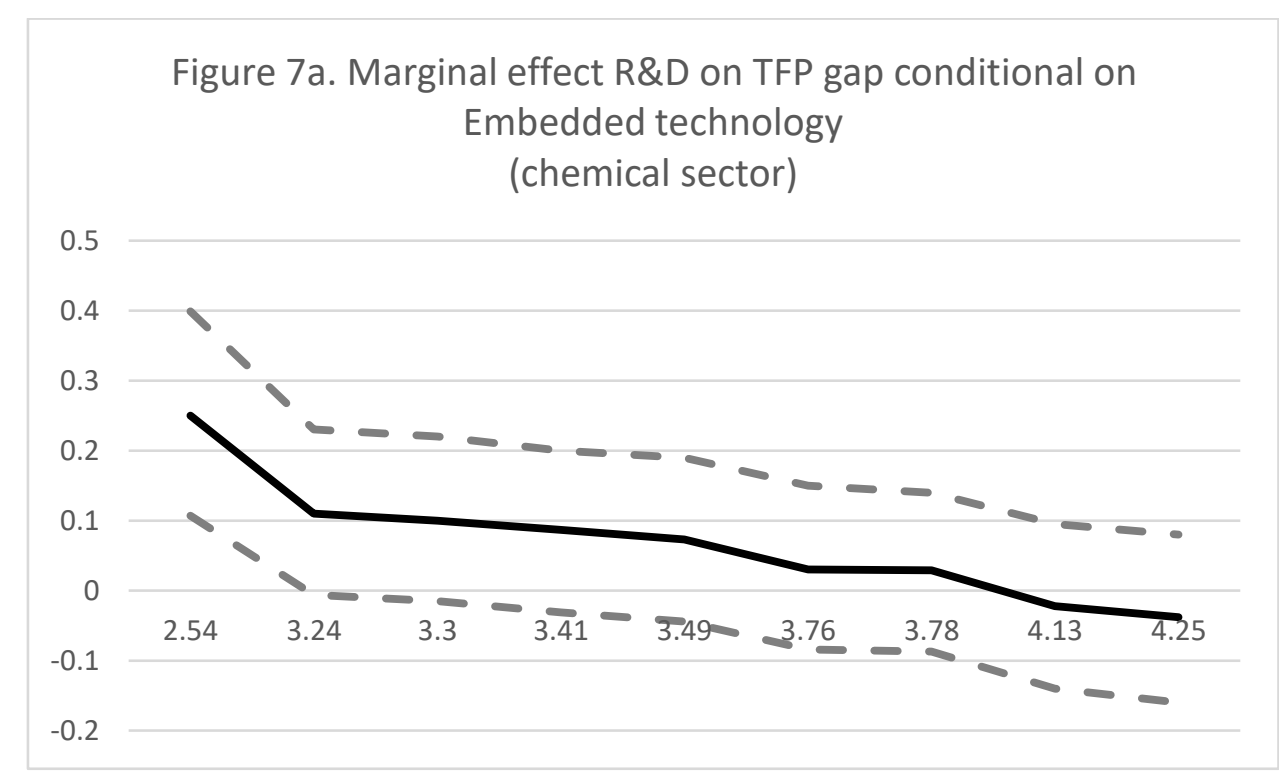




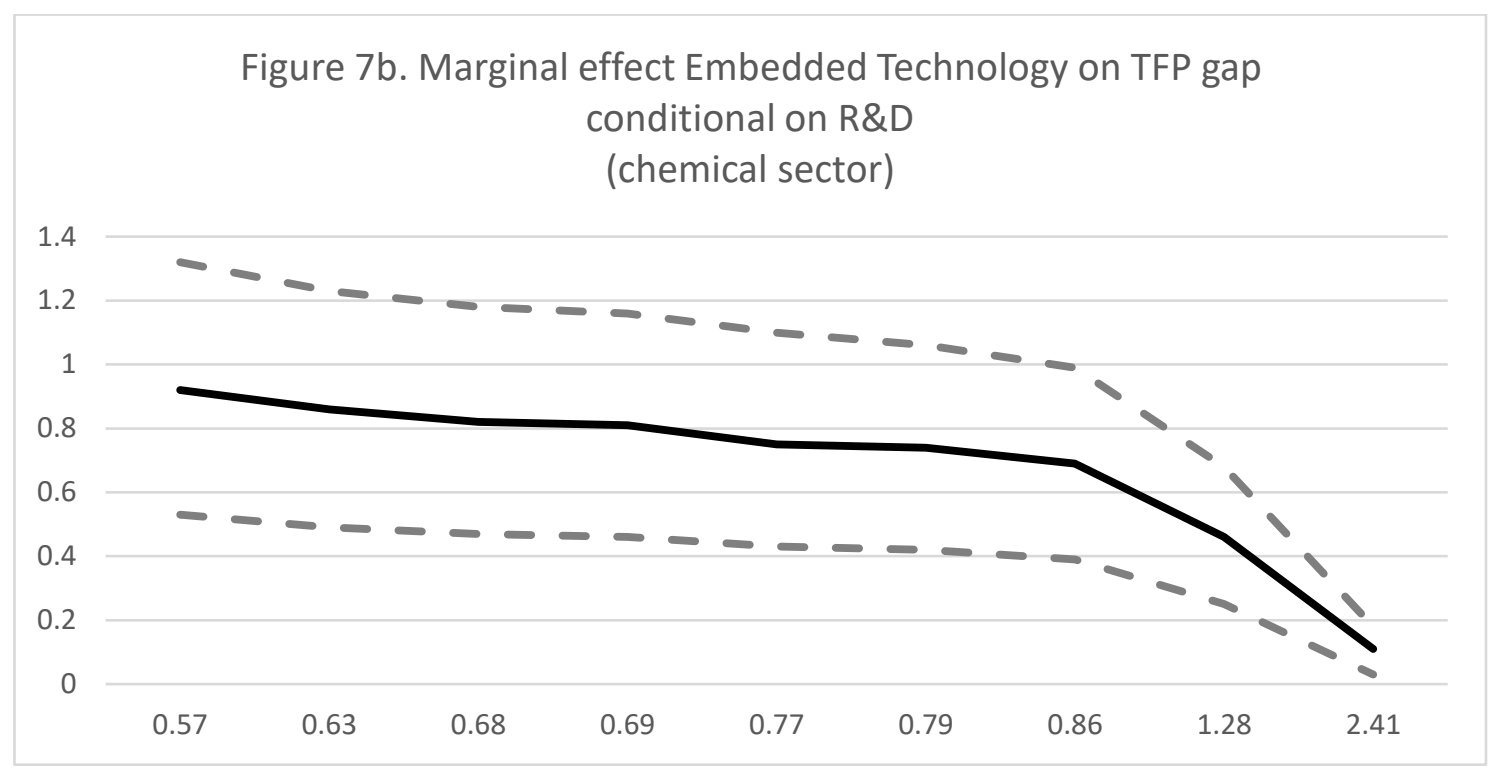

Source: Authors calculations based on regressions results from the FE weighted model

Basic Metal

For the basic metal sector, the marginal effects also reflect a gentle negative slope (figures $8 \mathrm{a}$ and $8 \mathrm{~b}$ ), but the effects are never significantly different from zero as exemplified by the wideness of the confidence intervals, always including the " 0 " effect line.

Figure 8a. Marginal effect R\&D on TFP gap conditional on Embedded technology

(basic metal sector)

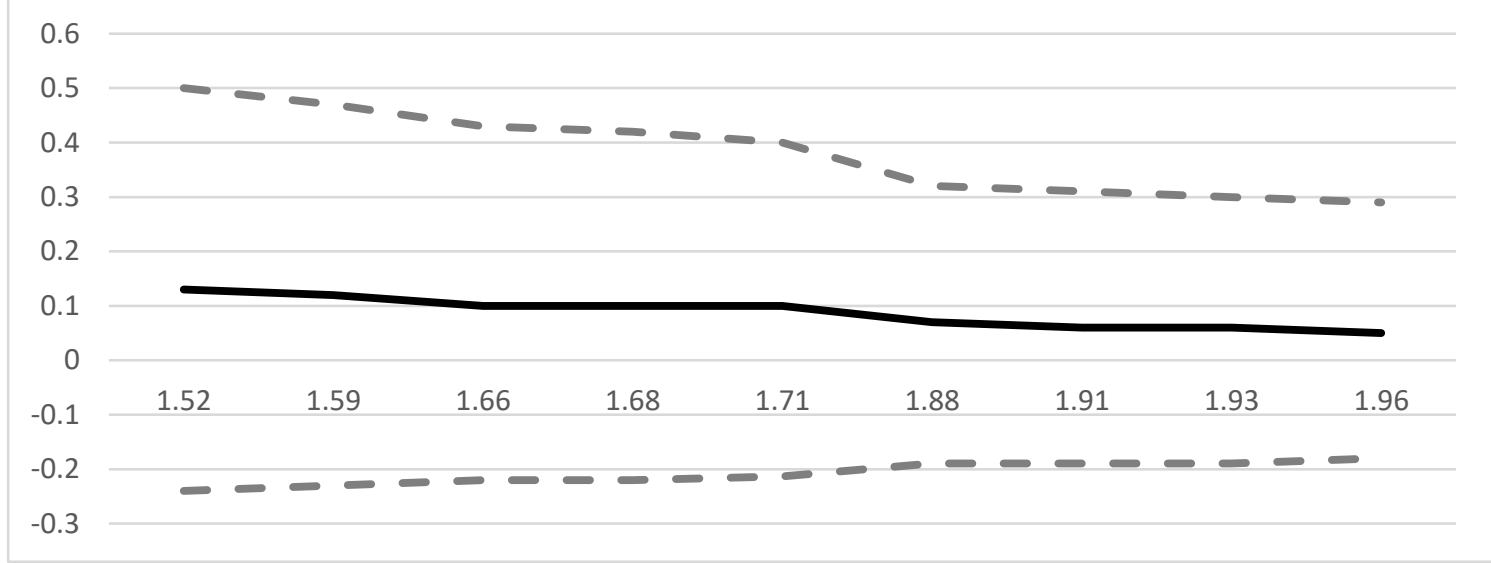




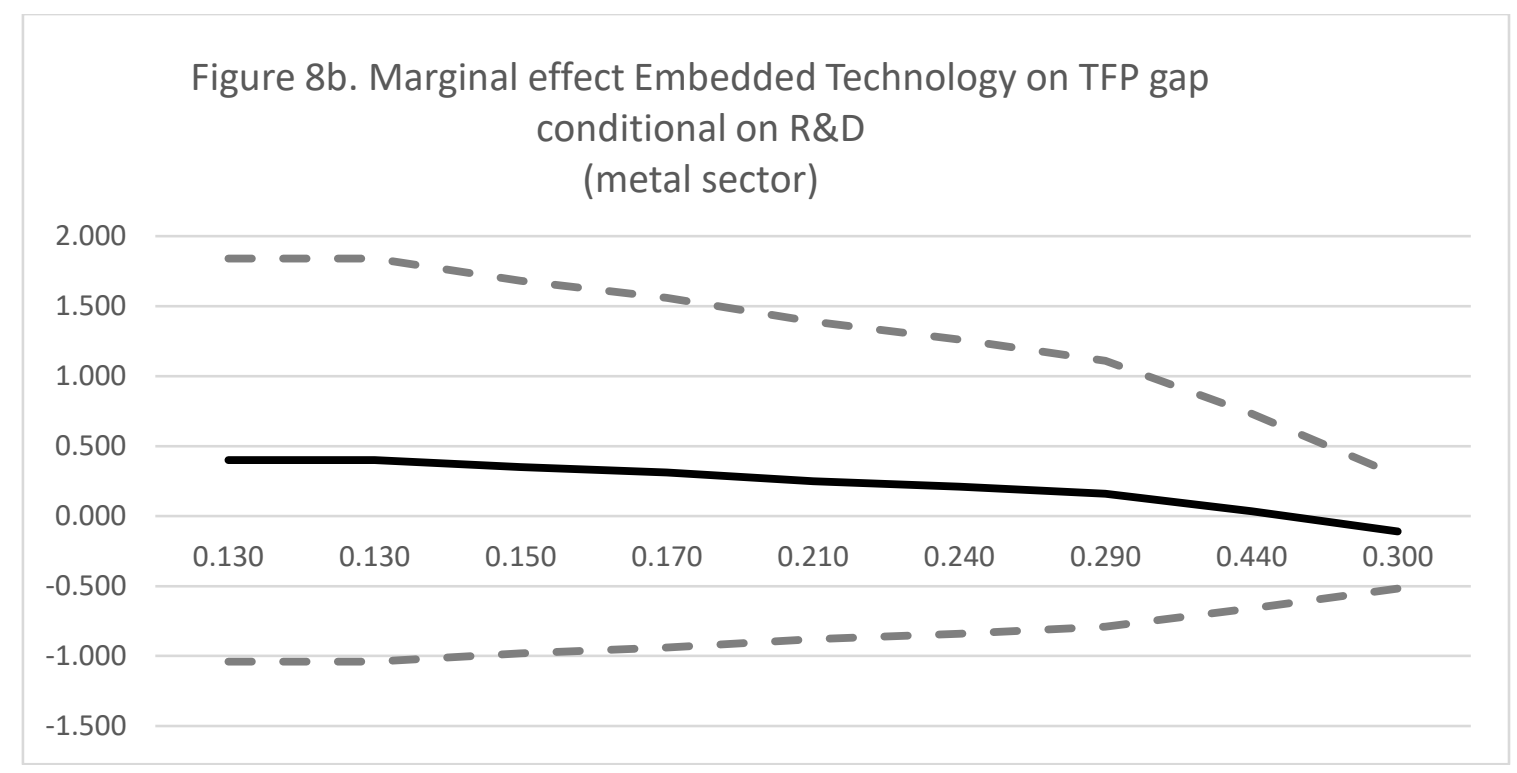

Source: Authors calculations based on regressions results from the FE weighted model

Food

Finally, the food sector has the highest coefficients for all three variables (R\&D, embedded R\&D and their interaction in table 4). The contribution of $R \& D$ to gap closure is significant and large for all values of embedded technology, and the contribution of embedded technology is also large in magnitude and significant for all values of own R\&D (figure 9a 9b). Although the marginal effects in this sector are the highest, they are also as in other sectors downward sloping, consistently with the negative sign of the interaction term. This indicates that also in food sector firms operating in subsectors with both high levels of investment in R\&D and embedded R\&D are less and less likely to close the productivity gap.

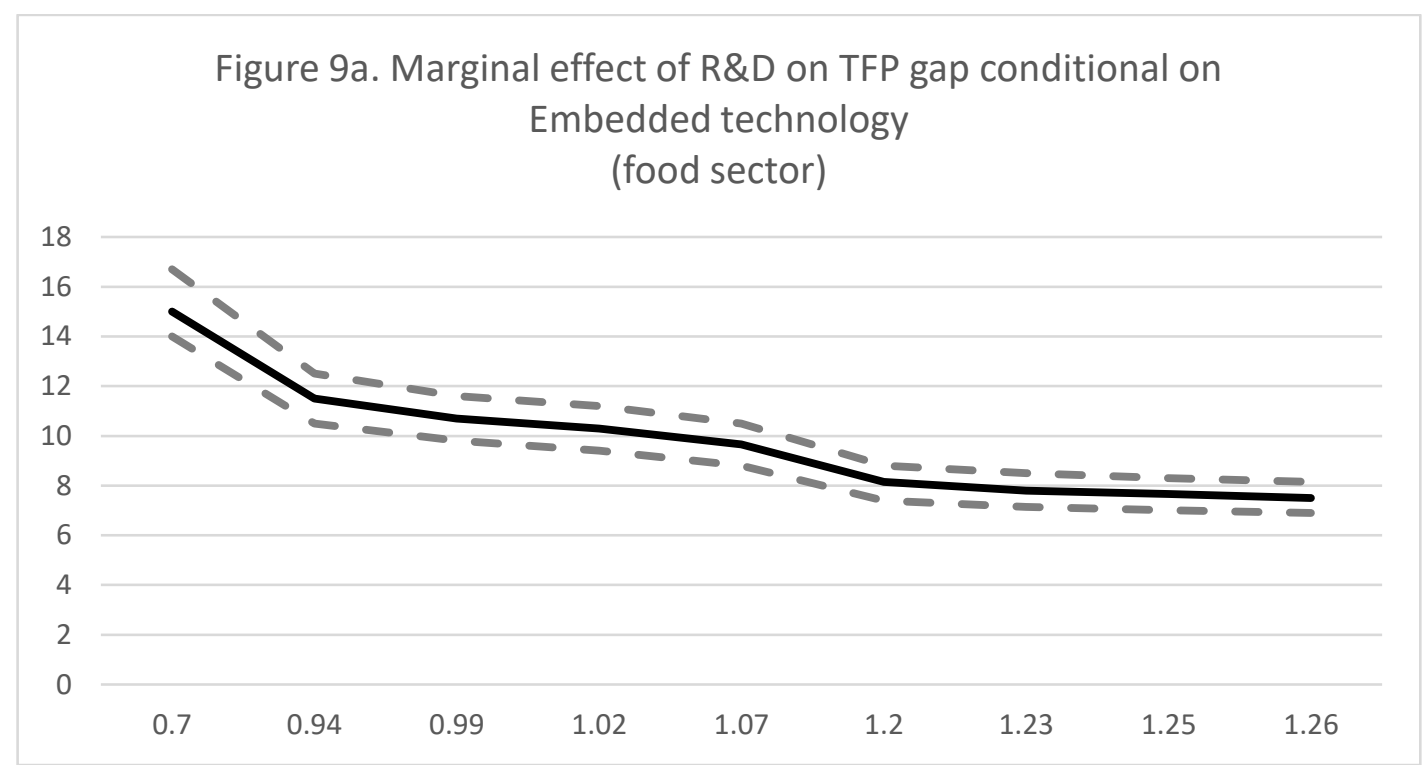




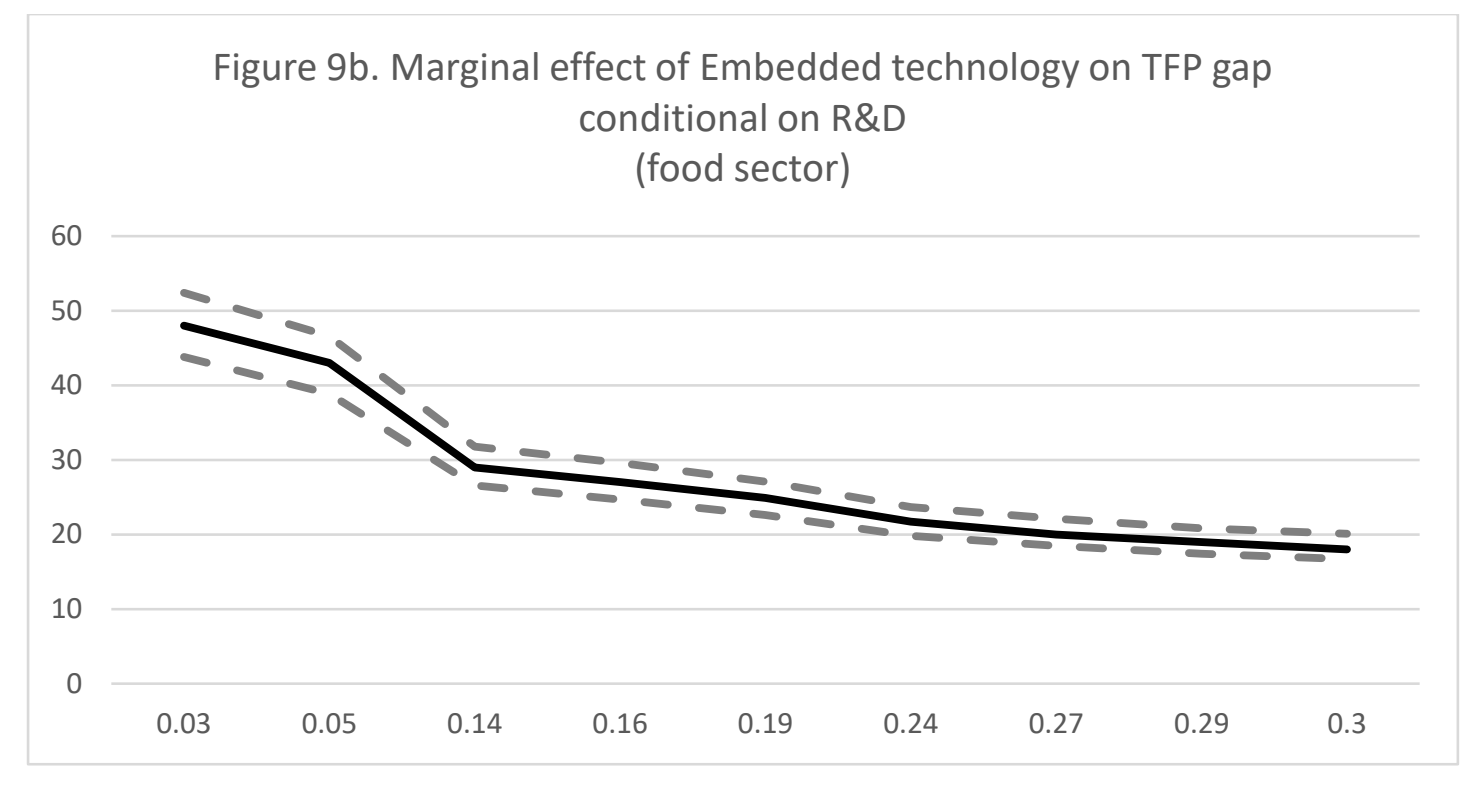

Source: Authors calculations based on regressions results from the FE weighted model

Our aim in this section was to explore how the (negative and significant) average coefficients for the interaction term between R\&D and embedded R\&D change along the distribution of own and embedded R\&D. The marginal effects of embedded technology on productivity gap are significant and consistently falling with increased R\&D intensity across all three sectors (computers, chemicals and food) for which this relationship is significant. On the other hand, the marginal effects of R\&D on TFP conditional on embedded technology are less consistent across three sectors. They vary in computers and chemicals, and are consistently significant and falling for the food sector. This suggests that the mismatches between R\&D and embedded R\&D are sector-specific. We note that the marginal effects for embedded technology are higher than for own R\&D in all three sectors where they are significant, and they also are consistently falling with increased R\&D intensity. As the sectors we analysed are economically very significant, and also very diverse, this might suggest that mismatches between R\&D and embedded R\&D are a broad feature of the EU innovation landscape, which deserves further research and policy makers' scrutiny.

\section{Conclusions and discussion}

In this paper, we have explored determinants of productivity gaps within the European Union in four manufacturing sectors of strong macroeconomic significance and varied R\&D intensity, namely Computers, Chemicals, Basic Metals and Food. Our exploration is probably the first one exploiting a multilevel framework to explore the determinants of the EU-wide productivity gap. This multilevel perspective offers new and robust insights into the nature of catching up in the European Union.

Our dataset enabled us to test the significance of firm-level variables (size and age), firm-level organisation (multi-plant firms and foreign ownership), market concentration at the country- and EUlevels, and of technology effort variables (own R\&D, embedded R\&D and interaction between them), while controlling for the time dimension (yearly dummies). 
We find that the productivity gap in the EU is very strongly related to technology variables - R\&D intensity in sub-sector and R\&D embedded in purchased equipment and machinery - and how they interact. While signs for both R\&D and embedded R\&D are as expected in most cases and reiterate the relevance of technology to closing the productivity gap, this is not the case with the interaction between these two variables. The coefficients estimated for our interaction variables are very significant and consistently negative in three out of four sectors. This negative relationship suggests that there is no complementarity between R\&D and embedded R\&D modes of technology acquisition, when this complementarity would be expected to be crucial for catching up (Radosevic, 1999). Instead, it seems that the two forms of R\&D are substitutes, suggesting a mismatch between R\&D investments and the level of R\&D embedded in imported machinery and equipment. What lies behind these mismatches would require further in-depth research by academics and policy makers alike. These mismatches might be due to wrong sequencing between R\&D investments and investment in imported machinery and equipment; the varied significance of these two forms of investments in different sectors; mismatches between $R \& D$ and forms of imported technology, in the form of machinery and equipment or imported know-how or patented licences; etc. However, irrespective of the actual cause, the bottom line is that these mismatches are actively contributing to increasing the productivity gaps within the EU.

In policy terms, this situation suggests that there is a lack of coordination between R\&D policy and technology transfer (FDI, trade and industrial policy). Given that our results show also that being a country of the EU periphery (South and East) contributes to a widening of the productivity gap, it seems that this mismatch is especially penalising for these laggards' countries. Indeed, our results confirm the existence of two types of regions in Europe: first, a rich and diverse region made of countries like Germany, Austria and Sweden ${ }^{15}$, and second a depleted regional ecosystem in EU South and either narrowly integrated (through branch plants), or similarly depleted regional innovation ecosystem in CEE.

Furthermore, our time dummies suggest that the root causes of the EU polarisation are not to be found in the 2008 crisis. It might have only magnified and accelerated processes, which have their structural origin in the lack of complementarities between strong and weak national and sectoral innovation systems in the EU. Finally, much of literature on determinants of productivity growth is concerned by firm and mezzo level variables like market concentration. Our results show that some of these variables are indeed important, but their explanatory power is much less significant than technology variables and varies across different sectors. The size of the firm is often significantly positively related to the closure of the productivity gap, which suggests that economies of scale continue to matter in the new growth regime dominated by ICT technologies. However, size should also be interpreted in the context of different levels of market concentration. Size and concentration are positively affecting the closure of the productivity gap at the EU-level, but market concentration alone within countries (as opposed to EU wide) deepens the productivity gap.

An unexpected result is the insignificant or significantly negative relationship between productivity gap and foreign ownership of firms and multiplant firms. If we consider the literature on FDI and multinational firms, this result may seem odd (Navaretti and Venables, 2004). However, we are testing

\footnotetext{
${ }^{15}$ For example, Germany has a vibrant industrial ecosystem with a diverse set of complementary capabilities suppliers, trade associations, industrial collective research consortia, industrial research centres (Berger, 2014).
} 
foreign ownership, and firm organisation as determinants of the overall productivity gap and these results demonstrate instead that FDI does not lead to productivity closure, for example if multinationals keep pushing the technological frontier. Significant literature on FDI spill-overs in the EU shows that the effects are ambiguous and far from conclusive (Bruno and Cipollina, 2017). Also, the literature on catching up shows that without domestic technology effort, only FDI will not suffice for growth (Chung and Lee, 2014; Radosevic, 1999; Mowery and Oxley, 1995). In that respect, our results are just confirming a robust stylised fact of development economics on the importance of interaction between R\&D and R\&D embedded in imported machinery and equipment as two modes of technology acquisition. What may seem 'unusual' is only that this stylised fact is being also confirmed in the case of developed world region as EU.

Our analysis contains powerful policy implications, which touch to the core of EU economic policies. A general policy lesson from our analysis is that technology catching up may become more effective when investments in R\&D are combined and complementary to access to foreign knowledge. More specifically conventional views on the EU productivity issues are explained or explored with reference to lags of periphery countries in structural reforms (Arpaia et al., 2007; Vergeer et al., 2015; Romisch et al., 2017; Campos et al., 2017), or to intra-Eurozone divergences caused by design defaults of the EMU (EC, 2010; Kollmann et al, 2015; Wyplosz et al, 2014; Flassbeck and Lapavitsas, 2013). A somewhat modified version of the conventional view is the recent World Bank study which explains productivity gap by below average 'opportunities' or combination of poorer educational outcomes and more burdensome regulations and lower support for firm innovation in many Southern and Central European countries (Ridao-Cano and Bodewig, 2018). These perspectives all point to macroeconomic or structural or institutional reforms of the EMU. From the perspective of our analysis, these perspectives do merit attention, but equally, our analysis shows that the root of productivity gaps are of long-term nature and rooted in technology gap factors. From a policy perspective, our results point to two crucial policy areas. First, it seems that the technology gap is not driven by R\&D policies, but by the disconnection between EU R\&D and other policies such as FDI and Global Value Chains policies. It seems that the EU has reached limits where only R\&D based policy can operate as a driver of technology convergence. In that context, further increases in R\&D intensity of CEE and South EU will have increasingly limited effects unless coupled with GVC/FDI policies.

These policies must provide incentives for technological capabilities to diffuse from the European core to the periphery, and they must entail investments into knowledge policies that support technological, organisational and institutional innovations in the periphery rather than only narrowly defined R\&D investments.

The challenge is to transform the EU's approach towards upgrading microeconomic assets and capabilities by focusing on cross-regional and international collaboration. A possible solution to EU regional imbalances is connecting and upscaling regional efforts in technology deployment. At the country-level, this would require much stronger linkages between innovation and FDI/GVC policy (Radosevic and Stancova, 2015). In a nutshell, our analysis points to a need to link up European regions with different technology and cost-levels through GVC-oriented industrial innovation policy.

We note that a limitation of our research is that we could not complement our data on import of embedded technology with data on import of know-how and patent licences as well as data on non$R \& D$ activities. This would have given a fuller picture of domestic knowledge-generation activities, as 
well as different forms of imported knowledge. It thus would have allowed for a better understanding of their interaction. Nevertheless, we consider our results to be a significant step towards a better understanding of how multilevel factors impact productivity gap, including the interaction between domestic and foreign technological knowledge as a critical factor of technology and productivity gap. 


\section{References:}

Aarstad, J., O. Kvitastein and S.E. Jakobsen (2016) "Related and Unrelated Variety as Regional Drivers of Enterprise Productivity and Innovation: A Multilevel Study" Research Policy 45, pages 844-856

Abramovitz, M. (1986), Catching up, Forging Ahead, and Falling Behind, The Journal of Economic History, 46, 2, 385-406.

Abramovitz, M., 1986. "Catching up, Forging Ahead, and Falling behind." Journal of Economic History

Acemoglu, Daron, Philippe Aghion and Fabrizio Zilibotti (2006), Distance to Frontier, Selection, and Economic Growth, Journal of the European Economic Association, Vol. 4, No. 1 (April 2006), pp. 37-74

Ackerberg, D. A., K. Caves, and G. Frazer. 2015. Identification properties of recent production function estimators. Econometrica 83: 2411-2451.

Acs Zoltan J. and David B. Audretsch (1988) Testing the Schumpeterian Hypothesis, Eastern Economic Journal, Vol. 14, No. 2 (Apr. - Jun. 1988), pp. 129-140

Aghion, P., Harmgart, H. \& Weisshaar, N. (2011). Fostering Growth in CEE Countries: A Countrytailored Approach to Growth Policy. In: Radosevic, S. \& Kaderabkova, A. eds.) Challenges for European Innovation Policy: Cohesion and Excellence from a Schumpeterian Perspective. Cheltenham, Edward Elgar Publishers

Aghion Philippe and Steven Durlauf (eds.) (2005) Handbook of Economic Growth. Elsevier,

Aghion, Philippe, and Peter Howitt. 2006. Appropriate growth policy: A unifying framework. Journal of the European Economic Association 4(2-3): 269-314.

Aghion, Philippe, Nick Bloom, Richard Blundell, Rachel Griffith, Peter Howitt, (2005) "Competition and Innovation: An Inverted-U Relationship, Quarterly Journal of Economics, Vol. 120, No. 2, pp. 701-728.

Aghion, Philippe, Richard Blundell, Rachel Griffith, Peter Howitt, Susanne Prantl, (2009) "The Effects of Entry on Incumbent Innovation and Productivity". Review of Economics and Statistics, February.

Alam Asad et al. (2008) Unleashing Prosperity. Productivity Growth in Eastern Europe and the Former Soviet Union, World Bank, Washington.

AlAzzawi, Shireen (2004), "Foreign Direct Investment and Knowledge Flows Evidence from Patent Citations" University of California, Davis, January 2004. https://ssrn.com/abstract=483322orhttp://dx.doi.org/10.2139/ssrn.483322

Altomonte, C., Aquilante, T., Gábor Békés and Ottaviano G.I.P. (2013). "Internationalization and Innovation of Firms: Evidence and Policy", Economic Policy, Volume 28, Issue 76, pages 663-700, October 2013.

Arpaia, Alfonso, Isabel Grilo, Werner Roeger, Janos Varga, Jan in 't Veld and Peter Wobst (2007) Quantitative Assessment of Structural Reforms: Modelling the Lisbon Strategy, European Economy Economic Papers, Number 282 - June 200, ECFIN.E3/REP/53283 
Bartelsman, Eric, John Haltiwanger, and Stefano Scarpetta (2013) Cross-Country Differences in Productivity: The Role of Allocation and Selection, American Economic Review 103(1): 305-334

Bartelsman, Eric, John Haltiwanger, Stefano Scarpetta (2009) Measuring and Analyzing Cross-country Differences in Firm Dynamics, In Timothy Dunne, J. Bradford Jensen, and Mark J. Roberts, editors, Producer Dynamics: New Evidence from Micro Data, University of Chicago Press

Bartelsman, Haltiwanger and Scarpetta (2004), Microeconomic Evidence of Creative Destruction in Industrial and Developing Countries, Discussion Paper No. 1374, October 2004, IZA

Bartelsman, Haltiwanger and Scarpetta (2013). Cross-country differences in Productivity: The Role of Allocation and Selection. American Economic Review 103(1), pages 305-334.

Basu S. and Weil D. N. (1998) Appropriate technology and growth, Quarterly Journal of Economics 113(4), 1025-1054.

Bell, M., and K. Pavitt. 1993. "Technological Accumulation and Industrial Growth: Contrasts between Developed and Developing Countries." Industrial and Corporate Change 2: 157-210.

Bellak Christian, 2004, How domestic and foreign firms differ and why does it matter, Journal of Economic Surveys, Vol. 18, No. 2

Berlingieri, G., S. Calligaris and C. Criscuolo (2018), "The productivity-wage premium: Does size still matter in a service economy?" OECD Science, Technology and Industry Working Papers, 2018/13, OECD Publishing, Paris. http://dx.doi.org/10.1787/04e36c29-en

Boyer, Robert (2014) The unsustainable divergence of national productive systems, Structural Change, Competitiveness and Industrial Policy, In Painful Lessons from the European Periphery, Edited By Aurora A. C. Teixeira, Ester Silva, Ricardo Mamede, Routledge

Bruno Randolph and Maria Cipollina (2017), A meta-analysis of the indirect impact of foreign direct investment in old and new EU member, states Understanding productivity spillovers, World Economy 2017;1-36. https://doi.org/10.1111/twec.12587

Campos, Nauro F., Paul De Grauwe and Yuemei Ji (2017) Structural Reforms, Growth and Inequality: An Overview of Theory, Measurement and Evidence Economics, IZA Discussion Paper Series, No. 11159, IZA - Institute of Labor Economics, Bonn

Castellacci, F. (2007) "Technological Regimes and Sectoral Differences in Productivity Growth" Industrial and Corporate Change, 16(6), pages 1105-1145.

Castellacci, F. (2011) 'Closing the Technology Gap? Review of Development Economics, Vol. 15, No. 1, pp.180-97

Castellani Davide, Mariacristina Piva, Torben Schubert and Marco Vivarelli (2019) R\&D and productivity in the USA and the EU: Sectoral specificities and differences in the crisis, Technological Forecasting and Social Change, vol. 138, pages 279-291. 
Cheung, Yin-Wong; Pascual, Antonio I. Garcia (2001): Market Structure, Technology Spillovers, and Persistence in Productivity Differentials, CESifo Working Paper, No. 517, Center for Economic Studies and Ifo Institute (CESifo), Munich

Cimoli, M., JB Pereima ad G. Porcile (2019) A technology gap interpretation of growth paths in Asia and Latin America, Research Policy 48: 125-136

Claudius Gräbner, Philipp Heimberger, Jakob Kapeller And Bernhard Schütz (2018) Structural Change in Times of Increasing Openness: Assessing Path Dependency in European Economic Integration, Working Paper 143, March, Vienna Institute for International Economic Studies (WIIW)

Cohen, W. M. and D. A. Levinthal (1989), "Innovation and learning: the two faces of R\&D", The Economic Journal, 99, pp. S.569-96.

Cohen, W. M. and D. A. Levinthal (1990), "Absorptive capacity: a new perspective on learning and innovation", Administrative Science Quarterly, 35, pp.128-52.

Damijan et al. (2013) Impact of Firm Heterogeneity on Direct and Spillover Effects of FDI: Micro Evidence from Ten Transition Countries, Journal of Comparative Economics 41 (2013) 895-922

Delgado-Rodríguez, M. J., and I. Álvarez-Ayuso. 2008. "Economic Growth and Convergence of EU Member States: An Empirical Investigation." Review of Development Economics 12: 486-497.

Denis, C. K. Mc Morrow, W. Röger and R. Veugelers (2005) The Lisbon Strategy and the EU's structural productivity problem, European Economy, N 221 February 2005, EC, DG for economic and financial affairs

Disney Richard, Helen Miller and Thomas Pope (2018) Firm-level investment spikes and aggregate investment over the Great Recession, IFS Working Paper W18/03, Institute for Fiscal Studies, London

Dobrinsky Rumen, Dieter Hesse and Rolf Traeger (2006) Understanding the long-term growth performance of the East European and CIS economies, Discussion Paper Series no. 9, United Nations Economic Commission for Europe, Economic Analysis Division

Doms, M., Dunne, T., (1998). Capital Adjustment Patterns in Manufacturing Plants. Review Economic Dynamics. 1, 409-429. https://doi.org/10.1006/redy.1998.0011

Dosi, G., Grazzi, M., Tomasi, C. et al. (2012) Turbulence underneath the big calm? The micro-evidence behind Italian productivity dynamics, Small Business Economics 39: 1043. https://doi.org/10.1007/s11187-011-9326-7

Eaton, J. and Kortum, S. (1999). 'International technology diffusion: theory and measurement', International Economic Review, Vol. 40, pp. 537-570.

EBRD (2013) Transition Report 2013, Stuck in Transition, European Bank for Reconstruction and Development, London

EC (2009) EU industrial structure 2009: Performance and Competitiveness, European Commission, DG Enterprise 
EC (2010) Surveillance of Intra-Euro-Area Competitiveness and Imbalances, EUROPEAN ECONOMY 1/2010, http://ec.europa.eu/economy finance/publications/european economy/2010/pdf/ee2010-1 en.pdf

EC (2017) Competitiveness in low-income and low-growth regions. The lagging regions report, Commission Staff Working Document, Brussels, 10.4.2017 SWD (2017) 132.

Fagerberg Jan and Bart Verspagen (2014) One Europe or Several? Causes and Consequences of the European Stagnation, Revised version of a paper presented at the "The Challenge for Europe in a New Age" workshop, Ålborg, 14-15 March 2013

Fagerberg, J. (1994) 'Technology and International Differences in Growth Rates', Journal of Economic Literature, Vol. 32, No. 3, pp.1147-75.

Fagerberg, Jan (1987). A technology gap approach to why growth rates differ, Research Policy, 16 (24): 87-99, DOI: 10.1016/0048-7333(87)90025-4.

Faggio, Giulia, Kjell G. Salvanes, and John Van Reenen. 2010. "The Evolution of Inequality in Productivity and Wages: Panel Data Evidence." Industrial and Corporate Change, 19(6): 1919-51.

Fare R., Grosskopf S., Noriss M. and Zhang Z. (1994) Productivity growth, technical progress, and efficiency change in industrialized countries, American Economic Review 84(1), 66-83.

Filipe Silva (2016) Research and Development, Innovation and Productivity Growth in the Steel Sector, DSTI/SU/SC(2015)5/FINAL, OECD Paris

Filippetti A. and A. Peyrache, (2013) Is the Convergence Party Over? Labour Productivity and the Technology Gap in Europe, Journal of Common Market Studies, pp.1-17, DOI:10.111/jcms12066

Filippetti Andrea \& Antonio Peyrache (2015) Labour Productivity and Technology Gap in European Regions: A Conditional Frontier Approach, Regional Studies, 49:4, 532-554, DOI: 10.1080/00343404.2013.799768

Filippetti Andrea \& Antonio Peyrache (2017) Productivity growth and catching up: a technology gap explanation, International Review of Applied Economics, 31:3, 283-303, DOI: 10.1080/02692171.2016.1249831

Filippetti, Andrea, Marion Frenz and Grazia letto-Gillies (2016) The impact of internationalization on innovation at countries level: the role of absorptive capacity, Cambridge Journal of Economics 2016; doi: 10.1093/cje/bew032

Flassbeck, Heiner and Lapavitsas, Costas, 2013, 'The Systemic Crisis of the Euro: True Causes and Effective Therapies', with H. Flassbeck., Rosa Luxemburg Stiftung Studien

Foster, L., Haltiwanger, J.C., Krizan, C.J., 2001. Aggregate Productivity Growth: Lessons from Microeconomic Evidence, in New Developments in Productivity Analysis. University of Chicago Press, pp. 303-372.

Franklin M. Fisher and Peter Temin (1979) The Schumpeterian Hypothesis: Reply, Journal of Political Economy 1979 87:2, 386-389 
Freeman (1995) Innovation and Growth, Chapter 7 in Handbook of Industrial Innovation, Edward Elgar Publishing. Edited by Mark Dodgson and Roy Rothwell

Freeman (1997) The Economics of Industrial Innovation, Routledge

Gardiner, B., Martin, R. and Tyler, P. (2004), Competitiveness, productivity and economic growth across the European Regions, Regional Studies, 38 (9), 1045-67.

Galindo-Rueda, F. and F. Verger (2016), "OECD Taxonomy of Economic Activities Based on R\&D Intensity", OECD Science, Technology and Industry Working Papers, No. 2016/04, OECD Publishing, Paris, https://doi.org/10.1787/5jlv73sqqp8r-en.

Gerschenkron, A., 1962. Economic Backwardness in Historical Perspective. Cambridge, MA: Belknap

Geylani, P.C., Stefanou, S.E., 2013. Linking investment spikes and productivity growth. Empirical Economics 45, 157-178. https://doi.org/10.1007/s00181-012-0599-8

Giuseppe Berlingieri, Patrick Blanchenay and Chiara Criscuolo (2017) The Great Divergence(S), OECD Science, Technology and Innovation Policy Papers, May 2017 No. 39

Gomulka Stanislaw (1971) Inventive Activity, Diffusion, and the Stages of Economic Growth, Aarhus, January,

Görg Holger and David Greenaway (2003) Much Ado About Nothing? Do Domestic Firms Really Benefit from Foreign Direct Investment? Discussion Paper series No, 94, Institute for the Study of Labor (IZA), November

Gorodnichenko, Yuriy, Debora Revoltella, Jan Svejnar and Christoph T. Weiss (2018) Resource Misallocation in European Firms: The Role Of Constraints, Firm Characteristics And Managerial Decisions, NBER Working Paper 24444, http://www.nber.org/papers/w24444

Gräbner, C., Heimberger, P., Kapeller, J., Schültz, B. (2017): Is Europe disintegrating? Macroeconomic divergence, structural polarization, trade, and fragility, WIIW Working Paper No. 136.

Gräbner, C., Heimberger, P., Kapeller, J., Schültz, B. (2018): Structural change in times of increasing openness: assessing path dependency in European integration, WIIW Working Paper No. 143.

Gradzewicz Michal (2018) What happens when firms invest? Investment events and firm performance, NBP Working Paper No. 291, National Bank of Poland.

Grazzi, M., Jacoby, N., Treibich, T., 2016. Dynamics of investment and firm performance: comparative evidence from manufacturing industries. Empirical Economics 51, 125-179. https://doi.org/10.1007/s00181-015-0991-2

Griffith, R., Redding, S. and Van Reenen, J. (2000), 'Mapping the two faces of R\&D: productivity growth in a panel of OECD industries', Centre for Economic Policy Research, Discussion Paper no. 2457.

Griffith, R., Redding, S. and Van Reenen, J. (2004). 'R\&D and absorptive capacity: from theory to data', The Scandinavian Journal of Economics, 32p. 
Griliches, Z. "Issues in Assessing the Contribution of Research and Development to Productivity Growth." The Bell Journal of Economics 10 (1979): 92-116.

Hall Robert E. and Charles I. Jones (1999) Why do some countries produce so much more output per worker than others? The Quarterly Journal of Economics, February 1999:83-116

Hall, Bronwyn H. Jacques Mairesse, and Pierre Mohnen (2010) Measuring the returns to R\&D, Chapter 24 in B. H. Hall and N. Rosenberg (editors), Handbook of the Economics of Innovation, Elsevier.

Hanousek, Jan, Evzen Kocenda, Mathilde Maurel (2010) Direct and indirect effects of FDI in emerging European markets: A survey and meta-analysis, Economic Systems 35 (2011) 301-322

Hopenhayn, Hugo, Julian Neira and Rish Singhania (2018) From population growth to firm demographics: implications for concentration, entrepreneurship and the labor share, NBER Working Paper 25382, http://www.nber.org/papers/w2538

Hsieh, C-T and P. J. Klenow (2009) Misallocation and manufacturing TFP in China and India. Quarterly Journal of Economics 124(4), pp 1403-1448

IMF (2013) IMF Multi-Country Report German-Central European Supply Chain - Cluster Report, IMF Country Report No. 13/263, August, Washington

Isaksson Anders (2007) Determinants of total factor productivity: a literature review, Research and Statistics Branch, United Nations Industrial Development Organization, July 2007

Jensen, J.B., McGuckin, R.H., Stiroh, K.J., 2001. The Impact of Vintage and Survival on Productivity: Evidence from Cohorts of U.S. Manufacturing Plants. Review of Economics and Statistics 83, 323-332. https://doi.org/10.1162/00346530151143851

Kim, Linsu (1997) Imitation to innovation; The dynamics of Korea's technological learning, Boston, Harvard University Press

Kinugasa, Tatsuo (1998) "The Schumpeterian hypothesis and technical change", International Journal of Social Economics, Vol. 25 Issue: 6/7/8, pp.1207-1216,

Klenow, P., Rodriguez-Clare, A., 1997. The neoclassical revival in growth economics: Has it gone too far? In: Bernanke, B., Rotemberg, J. (Eds.), NBER Macroeconomics Annual. MIT Press, Cambridge, MA.

Knell, M. (2008) 'Embodied technology diffusion and intersectoral linkages in Europe', Europe Innova Sectoral Innovation Watch deliverable WP4, Brussels: EC, available at http://www.europeinnova.eu/c/document_library/get_file?folderld=24913\&name=DLFE-2646.pdf

Kokko, Ari, Patrik Gustavsson Tingvall, and Josefin Videnord (2015) The Growth Effects of R\&D Spending in the EU: A Meta-Analysis, Discussion Paper, No. 2015-29, April 22, 2015, http://www.economics-ejournal.org/economics/discussionpapers/2015-29

Kollmann et al. (2015), "What drives the German current account? And how does it affect the other EU Member States?" Economic Policy, 2015, Vol. 30, pp.47-93. 
Kumar S. and Russell R. R. (2002) Technological change, technological catch-up, and capital deepening: relative contributions to growth and convergence, American Economic Review 92(3), 527-548.

Lall, S., 1992. "Technological Capabilities and Industrialization." World Development 20: 165-186.

Landes, D., 1969. The Unbound Prometheus. Cambridge: Cambridge University Press.

Landesman, M (2015) Structural Dynamics of Europe's Periphery - Which are the main issues?, In Journal of Economic Policy Reform, DOI: 10.1080/17487870.2015.1018691

Landesmann, A. Michael (2015) 'The new North-South Divide in Europe - Can the European Convergence Model be Resuscitated?', in: Jan Fagerberg, Staffan Laestadius and Ben R. Martin (eds.), The Triple Challenge for Europe: The Economy, Climate Change and Governance, Chapter 3, Oxford University Press, 2015

Landesmann, M., S. Leiner and R. Stehrer (2015) Competitiveness of the European Economy', EIB Working Paper, No. 2015/01, European Investment Bank

Lazonick William (2002) "The Theory of Innovative Enterprise", In Malcolm Warner, ed., International Encyclopaedia of Business and Management, Thomson Learning, 3055-3076.

Lazonick William (2002), Innovative enterprise and historical transformation, Enterprise and Society 3 (March), 3-37.

Levin, Richard C. Wesley M. Cohen and David C. Mowery (1985) R \& D Appropriability, Opportunity, and Market Structure: New Evidence on Some Schumpeterian Hypotheses, The American Economic Review, Vol. 75, No. 2, Papers and Proceedings of the Ninety-Seventh Annual Meeting of the American Economic Association (May, 1985), pp.20-24

Levinsohn, J., and A. Petrin. 2003. Estimating production functions using inputs to control for unobservables. Review of Economic Studies 70: 317-341.

Lipsey Robert E. (2002) Home and Host Country Effects of FDI, NBER Working Paper 9293, http://www.nber.org/papers/w9293

Maddison, A., 1995. Monitoring the World Economy 1820-1992. OECD Development Centre, Paris.

McKinsey (2019) Globalization In Transition: The Future Of Trade And Value Chains, McKinsey \& Company Global Institute

McMorrow, Kieran, Werner Röger, Alessandro Turrini (2010) Determinants of TFP growth: A close look at industries driving the EU-US TFP gap Structural Change and Economic Dynamics 21(2010)165-180

Moran, H. T., E.M. Graham and M. Blomstrom (2005) Does Foreign Direct Investment Promote Development? Institute for International Economics, Washington, April

Morton I. Kamien Nancy L. Schwartz (1976) On the Degree of Rivalry for Maximum Innovative Activity, The Quarterly Journal of Economics, Volume 90, Issue 2, 1 May 1976, Pages 245-260, 
Mowery David C. and Joanne E. Oxley (1995) Inward technology transfer and competitiveness: the role of national innovation systems, Cambridge Journal of Economics 1995, 19, 67-93

Navaretti Giorgio Barba and Anthony J. Venables (2004) Multinational Firms in the World Economy, Princeton University Press

Nelson R. Richard (1995) Co-evolution of industry structure, technology and supporting institutions, and the making of comparative advantage, International Journal of the Economics and Business, Vol. 2, No, 2: 171-184.

OECD (2014) Perspectives on Global Development 2014: Boosting Productivity to Meet the MiddleIncome Challenge, OECD, Paris

OECD (2018) Perspectives on Global Development 2019. Rethinking Development Strategies, OECD, Paris.

Parente S. L. and Prescott E. C. (1994) Barriers to technology adoption and development, Journal of Political Economy 102(2), 298-321

Pavitt, K. (1984). "Sectoral patterns of technical change: towards a taxonomy and a theory". Research Policy. 13 (6): 343-373. doi:10.1016/0048-7333(84)90018-0

Philip G. Gayle (2003) Market Concentration and Innovation: New Empirical Evidence on the Schumpeterian Hypothesis, Kansas State University, Chapter 3 of PhD dissertation

Posner, M. V. (1961) International Trade and Technical Change, Oxford Economic Papers, Volume 13, Issue 3, 1 October 1961, Pages 323-341

Power, L., 1998. The Missing Link: Technology, Investment, and Productivity. Review of Economics and Statistics. 80, 300-313. https://doi.org/10.1162/003465398557393

Prescott, E.C., 1998. Needed: A theory of total factor productivity. International Economic Review 39, $525-552$.

Radosevic, Slavo and Katerina Ciampi Stancova (2015) Internationalising Smart Specialisation: Assessment and Issues in the Case of EU New Member States, Journal of the Knowledge Economy, (DOI) 10.1007/s13132-015-0339-3 (open access article)

Restuccia, Diego and Richard Rogerson (2008) Policy distortions and aggregate productivity with heterogeneous establishments. Review of Economic Dynamics 11, pp. 707-720

Ridao-Cano Cristobal and Christian Bodewig (2018) Growing United. Upgrading Europe's Convergence Machine, World Bank, Washington

Rojec Matija and Mark Knell (2017) Why Is There a Lack of Evidence on Knowledge Spillovers From Foreign Direct Investment? Journal of Economic Surveys (2017) Vol. 00, No. 0, pp. 1-34

Römisch, Roman, Ruggero Fornoni, Lydia Greunz, Nirina Rabemiafara and Terry Ward (2017) Economic Challenges of Lagging Regions II: Recent Structural Reforms, Outstanding Needs and Governance Issues, WIIW Research Report 422, December, Vienna 
Sakellaris, P., 2004. Patterns of plant adjustment. Journal of Monetary Economics 51, 425-450.

Savvides, A. and M. Zachariadis, (2005) 'International Technology Diffusion and the Growth of TFP in the Manufacturing Sector of Developing Economies' Review of Development Economics 9, pp. 482-501

Scherer, F. M. (1967): Market Structure and the Employment of Scientists and Engineers. American Economic Review, 57, pp. 524-531.

Soete Luc (1979) Firm size and inventive activity: The evidence reconsidered, European Economic Review, Volume 12, Issue 4, October 1979, Pages 319-340

Stöllinger Roman (2016) Structural Change and Global Value Chains in the EU, WIIW Working Paper 127, July, Vienna

Sutton, J. (1998): Technology and Market Structure. Theory and History. MIT Press, Cambridge, MA.

Sveikauskas Leo 2007 R\&D and Productivity Growth: A Review of the Literature, Bureau of Labor Statistics Working Paper 408

Syverson, C., "What Determines Productivity?" Journal of Economic Literature, Vol. 49, No 2, 2011, pp. 326-365

The Conference Board Productivity Brief 2015, Available at http://www.conference-board.org

Van Ark, Bart, Mary O'Mahony, and Marcel P. Timmer The Productivity Gap between Europe and the United States: Trends and Causes, Journal of Economic Perspectives-Volume 22, Number 1-Winter 2008-Pages 25-44

Van Oort et al. (2012) "Multilevel Approaches to the Firm Agglomeration Ambiguity in Economic Growth Studies". Tinbergen Institute Discussion Paper, TI 2012-014/3

Van Reenen John (2018) Increasing Differences between firms: Market Power and the MacroEconomy, CEP Discussion Paper No 1576, September 2018, Centre for Economic Performance, London

Vergeer, Robert, Steven Dhondt, Alfred Kleinknecht and Karolus Kraan (2015) Will 'structural reforms' of labour markets reduce productivity growth? A firm-level investigation, European Journal of Economics and Economic Policies: Intervention, Vol. 12 No. 3, 2015, pp. 300-317

Wyplosz, C (2014), "The Eurozone Crisis: A Near-Perfect Case of Mismanagement", Economia Marche Journal of Applied Economics 33(1): 2-13.

Xiaohui Liu and Chenggang Wang (2003) Does foreign direct investment facilitate technological progress? Research Policy Volume 32, Issue 6, June 2003, Pages 945-953

Xu, Bin and Wang, Jianmao (1999), "Capital Goods Trade and R\&D Spillovers in the OECD," Canadian Journal of Economics (November 1999), pp. 1258-1274. 
Table A1: Descriptive statistics by sectors

Manufacturing of Computers (NACE 26)

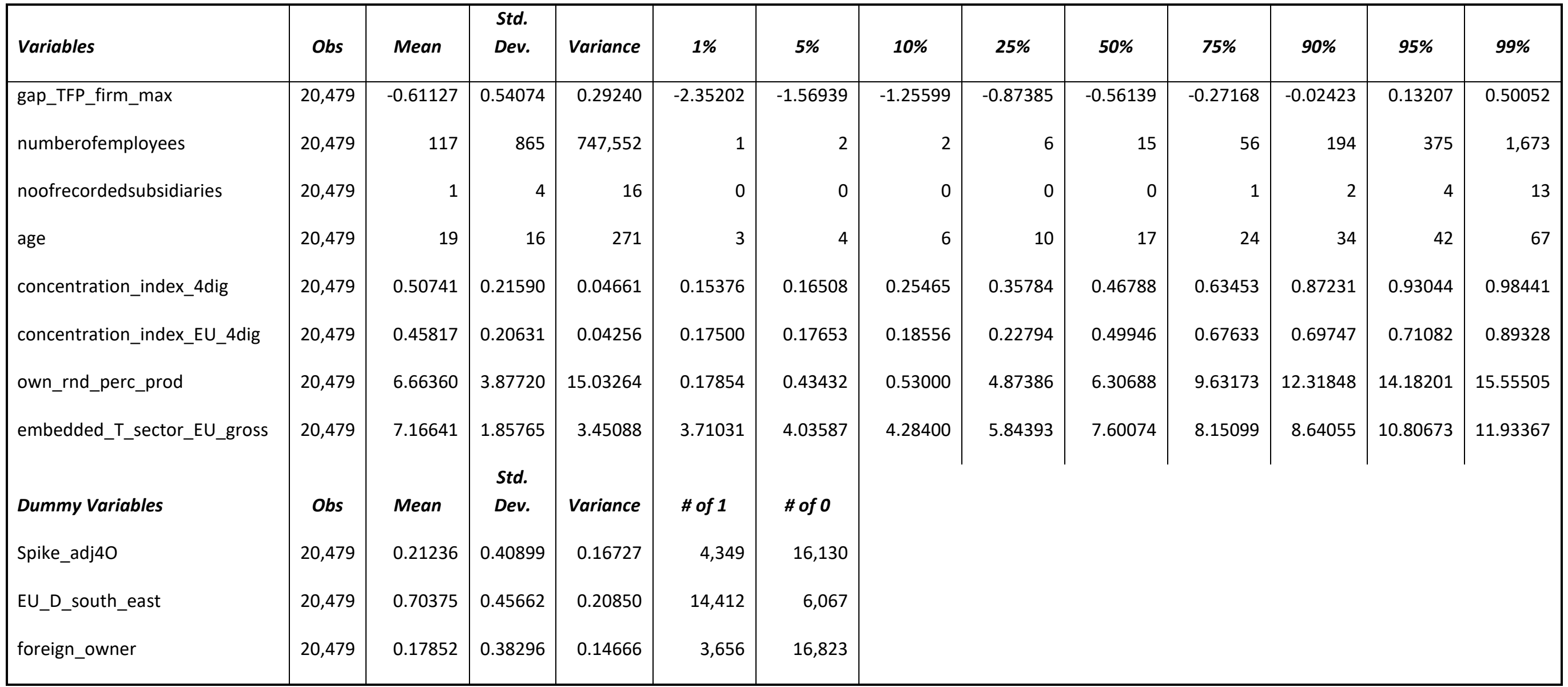


Manufacturing of Chemicals (NACE 20)

\begin{tabular}{|c|c|c|c|c|c|c|c|c|c|c|c|c|c|}
\hline Variables & Obs & Mean & $\begin{array}{l}\text { Std. } \\
\text { Dev. }\end{array}$ & Variance & $1 \%$ & $5 \%$ & $10 \%$ & $25 \%$ & $50 \%$ & $75 \%$ & $90 \%$ & $95 \%$ & $99 \%$ \\
\hline gap_TFP_firm_max & 25,147 & -0.68363 & 0.51416 & 0.26436 & -2.18350 & -1.54295 & -1.29265 & -0.96267 & -0.64563 & -0.35371 & -0.09921 & 0.04636 & 0.40034 \\
\hline numberofemployees & 25,147 & 101 & 584 & 341,072 & 1 & 2 & 4 & 9 & 24 & 71 & 201 & 383 & 1,113 \\
\hline noofrecordedsubsidiaries & 25,147 & 1 & 4 & 19 & 0 & 0 & 0 & 0 & 0 & 1 & 3 & 5 & 16 \\
\hline age & 25,147 & 24 & 19 & 344 & 3 & 5 & 7 & 12 & 19 & 29 & 45 & 58 & 89 \\
\hline concentration_index_4dig & 25,147 & 0.55860 & 0.21532 & 0.04636 & 0.20121 & 0.23143 & 0.26566 & 0.36875 & 0.57455 & 0.72079 & 0.86667 & 0.93945 & 0.99952 \\
\hline concentration_index_EU_4dig & 25,147 & 0.37640 & 0.21012 & 0.04415 & 0.13092 & 0.13671 & 0.14290 & 0.15824 & 0.29514 & 0.57044 & 0.66173 & 0.71349 & 0.90861 \\
\hline own_rnd_perc_prod & 25,147 & 0.96563 & 0.65191 & 0.42499 & 0.05102 & 0.22803 & 0.63191 & 0.67154 & 0.76190 & 0.87122 & 2.45075 & 2.59367 & 2.93157 \\
\hline embedded_T_sector_EU_gross & 25,147 & 3.50921 & 0.78029 & 0.60885 & 1.50465 & 2.24265 & 2.51210 & 3.25908 & 3.49032 & 3.86331 & 4.20555 & 4.25348 & 6.77413 \\
\hline & & & Std. & & & & & & & & & & \\
\hline Dummy Variables & Obs & Mean & Dev. & Variance & $\#$ of 1 & $\#$ of 0 & & & & & & & \\
\hline Spike_adj40 & 25,147 & 0.12029 & 0.32531 & 0.10583 & 3,025 & 22,122 & & & & & & & \\
\hline EU_D_south_east & 25,147 & 0.78105 & 0.41354 & 0.17102 & 19,641 & 5,506 & & & & & & & \\
\hline foreign_owner & 25,147 & 0.23355 & 0.42310 & 0.17901 & 5,873 & 19,274 & & & & & & & \\
\hline
\end{tabular}


Manufacturing of Basic Metal (NACE 24)

\begin{tabular}{|c|c|c|c|c|c|c|c|c|c|c|c|c|c|}
\hline Variables & Obs & Mean & Std. Dev. & Variance & $1 \%$ & $5 \%$ & $10 \%$ & $25 \%$ & $50 \%$ & $75 \%$ & $90 \%$ & $95 \%$ & $99 \%$ \\
\hline gap_TFP_firm_max & 16,617 & -0.69044 & 0.54848 & 0.30083 & -2.37402 & -1.61801 & -1.33420 & -0.96497 & -0.63631 & -0.33785 & -0.08338 & 0.04624 & 0.33229 \\
\hline numberofemployees & 16,617 & 173 & 757 & 573,530 & 1 & 3 & 5 & 11 & 34 & 109 & 320 & 620 & 2,512 \\
\hline noofrecordedsubsidiaries & 16,617 & 1 & 4 & 14 & 0 & 0 & 0 & 0 & 0 & 1 & 3 & 5 & 14 \\
\hline age & 16,617 & 25 & 21 & 437 & 3 & 5 & 6 & 12 & 19 & 32 & 48 & 58 & 100 \\
\hline concentration_index_4dig & 16,617 & 0.59810 & 0.18326 & 0.03358 & 0.24422 & 0.30764 & 0.36548 & 0.46616 & 0.58194 & 0.72004 & 0.85253 & 0.96055 & 1.00000 \\
\hline concentration_index_EU_4dig & 16,617 & 0.32595 & 0.14586 & 0.02128 & 0.17697 & 0.19837 & 0.20580 & 0.22273 & 0.27486 & 0.37512 & 0.50348 & 0.68220 & 0.81211 \\
\hline own_rnd_perc_prod & 16,617 & 0.32554 & 0.30776 & 0.09472 & 0.00589 & 0.07363 & 0.12901 & 0.15336 & 0.21181 & 0.31761 & 0.76909 & 1.02593 & 1.47325 \\
\hline embedded_T_sector_EU_gross & 16,617 & 1.73256 & 0.19572 & 0.03831 & 1.33640 & 1.41808 & 1.48726 & 1.58316 & 1.70929 & 1.90618 & 1.94227 & 2.00461 & 2.22192 \\
\hline Dummy Variables & Obs & Mean & Std. Dev. & Variance & \# of 1 & \# of 0 & & & & & & & \\
\hline Spike_adj40 & 16,617 & 0.16736 & 0.37331 & 0.13936 & 2,781 & 13,836 & & & & & & & \\
\hline EU_D_south_east & 16,617 & 0.76121 & 0.42636 & 0.18178 & 12,649 & 3,968 & & & & & & & \\
\hline foreign_owner & 16,617 & 0.17223 & 0.37759 & 0.14258 & 2,862 & 13,755 & & & & & & & \\
\hline
\end{tabular}


Manufacturing of Food (NACE 10)

\begin{tabular}{|c|c|c|c|c|c|c|c|c|c|c|c|c|c|}
\hline Variables & Obs & Mean & $\begin{array}{l}\text { Std. } \\
\text { Dev. }\end{array}$ & Variance & $1 \%$ & $5 \%$ & $10 \%$ & $25 \%$ & $50 \%$ & $75 \%$ & $90 \%$ & $95 \%$ & $99 \%$ \\
\hline gap_TFP_firm_max & 81,666 & -0.77860 & 0.59237 & 0.35090 & -2.52924 & -1.83538 & -1.51356 & -1.08674 & -0.71188 & -0.39481 & -0.12736 & 0.02995 & 0.42137 \\
\hline numberofemployees & 81,666 & 70 & 368 & 135,746 & 1 & 2 & 3 & 7 & 16 & 44 & 136 & 242 & 776 \\
\hline noofrecordedsubsidiaries & 81,666 & 1 & 3 & 8 & 0 & 0 & 0 & 0 & 0 & 0 & 2 & 3 & 8 \\
\hline age & 81,666 & 20 & 17 & 276 & 3 & 4 & 6 & 10 & 17 & 25 & 39 & 50 & 82 \\
\hline concentration_index_4dig & 81,666 & 0.39116 & 0.20086 & 0.04035 & 0.04650 & 0.12151 & 0.13622 & 0.24819 & 0.37870 & 0.47350 & 0.67790 & 0.79694 & 0.96966 \\
\hline concentration_index_EU_4dig & 81,666 & 0.21505 & 0.13859 & 0.01921 & 0.07994 & 0.08050 & 0.08115 & 0.10184 & 0.17787 & 0.25978 & 0.44016 & 0.53773 & 0.60204 \\
\hline own_rnd_perc_prod & 81,666 & 0.19686 & 0.11645 & 0.01356 & 0.00720 & 0.02042 & 0.03374 & 0.13817 & 0.22549 & 0.26786 & 0.30890 & 0.32121 & 0.71693 \\
\hline embedded_T_sector_EU_gross & 81,666 & 1.06731 & 0.21838 & 0.04769 & 0.60492 & 0.65087 & 0.70378 & 0.97759 & 1.07412 & 1.24350 & 1.24983 & 1.32464 & 1.49876 \\
\hline Dummy Variables & Obs & Mean & Dev. & Variance & \# of 1 & $\#$ of 0 & & & & & & & \\
\hline Spike_adj40 & 81,666 & 0.12959 & 0.33585 & 0.11280 & 10,583 & 71,083 & & & & & & & \\
\hline EU_D_south_east & 81,666 & 0.76132 & 0.42628 & 0.18171 & 62,174 & 19,492 & & & & & & & \\
\hline foreign_owner & 81,666 & 0.11567 & 0.31983 & 0.10229 & 9,446 & 72,220 & & & & & & & \\
\hline
\end{tabular}


Table A2: List of variables and their description

\begin{tabular}{|c|c|c|c|}
\hline Stata Variables & Variable Name & Description & Source \\
\hline gap_TFP_firm_max & $\begin{array}{l}\text { TFP GAP /Ln(Firm_TFP)- } \\
\text { Ln(EU_frontier)-4Digit(t)/ }\end{array}$ & $\begin{array}{l}\text { Three Steps procedure: } 1 \text { ) Collection of Residuals of a TFP 4-digit } \\
\text { regression on the whole sample; } 2 \text { ) Computation of EU Frontier TFP level } \\
\text { within each 4-digit; 3) Firm-level TFP minus EU frontier. Positive values } \\
\text { indicate firms above the frontier, negative values below. }\end{array}$ & $\begin{array}{l}\text { Authors computations } \\
\text { using Amadeus BvD @ }\end{array}$ \\
\hline numberofemployees & Number of Employees(t) & Number of firm's employees & Amadeus BvD C \\
\hline noofrecordedsubsidiaries & $\begin{array}{l}\text { Number of Recorded } \\
\text { Subsidiaries(last available year) }\end{array}$ & Number of the firm's subsidiaries & Amadeus BvD C \\
\hline age & Age(t) & $\begin{array}{l}\text { Age represents the number of years that the firm operates calculated as } \\
\text { the current year of the observation minus the foundation year. }\end{array}$ & $\begin{array}{l}\text { Authors computations } \\
\text { using Amadeus BvD C } \\
\text { information on "year of } \\
\text { incorporation." }\end{array}$ \\
\hline concentration_index_4dig & Concentration Index(t) & $\begin{array}{l}\text { Market Share of top } 4 \text { firms (turnover) within each sector (based on 4difit } \\
\text { NACE rev.2) \& within each country }\end{array}$ & Amadeus BvD (C) \\
\hline concentration_index_EU_4dig & Concentration Index EU(t) & $\begin{array}{l}\text { Market Share of top } 4 \text { firms (turnover) within each sector (based on 4difit } \\
\text { NACE rev.2) across the whole European Union }\end{array}$ & Amadeus BvD @ \\
\hline own_rnd_perc_prod & Own R\&D (t) & $\begin{array}{l}\text { Percentage of Business production value spend on R\&D. Calculated as } \\
\text { Business Expenditure on R\&D in millions of EUR divided by production } \\
\text { value in millions of EUR multiplied by } 100\end{array}$ & BERD (NACE2) \\
\hline
\end{tabular}




\begin{tabular}{|c|c|c|c|}
\hline embedded_T_sector_EU_gross & Embedded R\&D(t) & $\begin{array}{l}\text { Percentage of R\&D imported from other technology-weighted-sectors } \\
\text { within the European Union (including domestic) as a percentage of GVA }\end{array}$ & $\begin{array}{l}\text { BERD (NACE2) Eurostat } \\
\text { combined with WIOD }\end{array}$ \\
\hline \multicolumn{4}{|l|}{ Dummy Variables } \\
\hline Spike_adj40 & Spike dummy(t) & $\begin{array}{l}1 \text { if the previous year ratio of investment in capital is higher than } 20 \% \text {. This } \\
\text { variable capture the so-called "investment lumpiness" phenomenon. } \\
\text { Companies with "lumpy investment", i.e. volatile capital "shifts" might } \\
\text { experience more erratic performance patterns. }\end{array}$ & $\begin{array}{l}\text { Authors computations } \\
\text { using Amadeus BvD @ } \\
\text { information on "ratio of } \\
\text { investment on capital." }\end{array}$ \\
\hline EU_D_south_east & EU dummy(fixed) & $\begin{array}{l}\text { Dummy variable that is equal to } 1 \text { if the country is located in East or South } \\
\text { of Europe, } 0 \text { otherwise }\end{array}$ & $\begin{array}{l}\text { Authors computation } \\
\text { using Eurostat }\end{array}$ \\
\hline foreign_owner & $\begin{array}{l}\text { Foreign Owner dummy(last } \\
\text { available year) }\end{array}$ & $\begin{array}{l}\text { Dummy Variable that is equal to } 1 \text { if the firm has a foreign owner, } 0 \\
\text { otherwise }\end{array}$ & $\begin{array}{l}\text { Authors computations } \\
\text { using Amadeus BvD @ } \\
\text { information on "foreign } \\
\text { ownership." }\end{array}$ \\
\hline
\end{tabular}


Appendix table A3: Marginal effect analysis

\section{Computing sector (26)}

Table A.3.1.a Marginal effect of R\&D on TFP gap conditional on Embedded Technology

\begin{tabular}{|c|c|c|c|c|c|c|c|}
\hline \multicolumn{2}{|c|}{$\begin{array}{l}\text { Embedded } \\
\text { technology }\end{array}$} & coefficient & se & z st. & $p$-value & $\begin{array}{l}95 \% \text { confidence } \\
\text { interval, lower } \\
\text { value }\end{array}$ & $\begin{array}{l}\text { 95\% confidence } \\
\text { interval, upper } \\
\text { value }\end{array}$ \\
\hline mean & 7.56 & -0.039 & 0.049 & -0.79 & 0.427 & -0.134 & 0.06 \\
\hline $10^{\text {th }}$ centile & 4.84 & 0.11 & 0.049 & 2.34 & 0.019 & 0.019 & 0.210 \\
\hline $20^{\text {th }}$ centile & 5.84 & 0.05 & 0.05 & 1.06 & 0.29 & -0.043 & 0.140 \\
\hline $30^{\text {th }}$ centile & 6.26 & 0.026 & 0.05 & 0.55 & 0.582 & -0.067 & 0.120 \\
\hline $40^{\text {th }}$ centile & 7.41 & -0.03 & 0.05 & -0.66 & 0.51 & -0.128 & 0.063 \\
\hline $50^{\text {th }}$ centile & 7.82 & -0.05 & 0.5 & -1.03 & 0.304 & -0.149 & 0.050 \\
\hline $60^{\text {th }}$ centile & 7.94 & -0.056 & 0.05 & -1.12 & 0.263 & -0.150 & 0.040 \\
\hline $70^{\text {th }}$ centile & 8.21 & -0.07 & 0.51 & -1.22 & 0.182 & -0.170 & 0.030 \\
\hline $80^{\text {th }}$ centile & 8.43 & -0.077 & 0.05 & -1.5 & 0.135 & -0.178 & 0.024 \\
\hline $90^{\text {th }}$ centile & 10.81 & -0.16 & 0.06 & -2.76 & 0.006 & -0.279 & -0.047 \\
\hline
\end{tabular}

Table A.3.1.b Marginal effect of Embedded Technology on TFP gap conditional on own R\&D

\begin{tabular}{|c|c|c|c|c|c|c|c|}
\hline \multicolumn{2}{|c|}{ Own R\&D } & coefficient & se & z st. & $p$-value & value & value \\
\hline mean & 6.39 & 0.15 & 0.04 & 3.32 & 0.001 & 0.06 & 0.23 \\
\hline $10^{\text {th }}$ centile & 0.53 & 1.01 & 0.19 & 5.27 & 0.000 & 0.640 & 1.390 \\
\hline $20^{\text {th }}$ centile & 3.39 & 0.37 & 0.08 & 4.6 & 0.000 & 0.210 & 0.530 \\
\hline $30^{\text {th }}$ centile & 4.97 & 0.23 & 0.58 & 4.03 & 0.000 & 0.120 & 0.350 \\
\hline $40^{\text {th }}$ centile & 5.24 & 0.22 & 0.055 & 3.92 & 0.000 & 0.101 & 0.330 \\
\hline $50^{\text {th }}$ centile & 6.17 & 0.16 & 0.046 & 3.45 & 0.000 & 0.069 & 0.250 \\
\hline $60^{\text {th }}$ centile & 6.46 & 0.14 & 0.04 & 3.28 & 0.000 & 0.06 & 0.230 \\
\hline $70^{\text {th }}$ centile & 8.16 & 0.06 & 0.03 & 1.94 & 0.053 & -0.001 & 0.127 \\
\hline $80^{\text {th }}$ centile & 10.36 & -0.02 & 0.024 & -0.79 & 0.432 & -0.070 & 0.029 \\
\hline $90^{\text {th }}$ centile & 11.33 & -0.05 & 0.023 & -2.18 & 0.029 & -0.096 & -0.005 \\
\hline
\end{tabular}




\section{Chemical sector (20)}

Table A.3.2.a Marginal effect of R\&D on TFP gap conditional on Embedded Technology

\begin{tabular}{|c|c|c|c|c|c|c|c|}
\hline \multicolumn{2}{|c|}{$\begin{array}{l}\text { Embedded } \\
\text { technology }\end{array}$} & \multirow{2}{*}{$\begin{array}{r}\text { coefficient } \\
0.059\end{array}$} & \multirow{2}{*}{$\begin{array}{l}\text { se } \\
0.059\end{array}$} & \multirow{2}{*}{$\begin{array}{l}\text { z st. } \\
0.99\end{array}$} & \multirow{2}{*}{$\begin{array}{r}p \text {-value } \\
0.320\end{array}$} & \multirow{2}{*}{$\begin{array}{l}\text { 95\% confidence } \\
\text { interval, lower } \\
\text { value } \\
\quad-.057\end{array}$} & \multirow{2}{*}{$\begin{array}{l}\text { 95\% confidence } \\
\text { interval, upper } \\
\text { value } \\
.175\end{array}$} \\
\hline mean & 3.58 & & & & & & \\
\hline $10^{\text {th }}$ centile & 2.54 & 0.25 & 0.74 & 3.4 & 0.001 & 0.107 & 0.399 \\
\hline $20^{\text {th }}$ centile & 3.24 & 0.11 & 0.06 & 1.87 & 0.06 & -0.006 & 0.230 \\
\hline $30^{\text {th }}$ centile & 3.3 & 0.1 & 0.06 & 1.72 & 0.085 & -0.015 & 0.220 \\
\hline $40^{\text {th }}$ centile & 3.41 & 0.087 & 0.06 & 1.45 & 0.147 & -0.031 & 0.200 \\
\hline $50^{\text {th }}$ centile & 3.49 & 0.073 & 0.06 & 1.23 & 0.22 & -0.044 & 0.190 \\
\hline $60^{\text {th }}$ centile & 3.76 & 0.03 & 0.06 & 0.54 & 0.589 & -0.084 & 0.150 \\
\hline $70^{\text {th }}$ centile & 3.78 & 0.029 & 0.06 & 0.48 & 0.628 & -0.087 & 0.140 \\
\hline $80^{\text {th }}$ centile & 4.13 & -0.022 & 0.06 & -0.37 & 0.714 & -0.14 & 0.095 \\
\hline $90^{\text {th }}$ centile & 4.25 & -0.038 & 0.06 & -0.63 & 0.526 & -0.160 & 0.080 \\
\hline
\end{tabular}

Table A.3.2.b Marginal effect of Embedded Technology on TFP gap conditional on own R\&D

\begin{tabular}{|c|c|c|c|c|c|c|c|}
\hline \multicolumn{2}{|c|}{ Own R\&D } & coefficient & se & z st. & p-value & $\begin{array}{l}95 \% \text { confidence } \\
\text { interval, lower } \\
\text { value }\end{array}$ & $\begin{array}{l}95 \% \text { confidence } \\
\text { interval, upper } \\
\text { value }\end{array}$ \\
\hline mean & 0.99 & 0.61 & 0.14 & 4.43 & 0.000 & 0.34 & 0.879 \\
\hline $10^{\text {th }}$ centile & 0.570 & 0.920 & 0.200 & 4.610 & 0.000 & 0.530 & 1.320 \\
\hline $20^{\text {th }}$ centile & 0.630 & 0.860 & 0.190 & 4.600 & 0.000 & 0.490 & 1.230 \\
\hline $30^{\text {th }}$ centile & 0.680 & 0.820 & 0.180 & 4.570 & 0.000 & 0.470 & 1.180 \\
\hline $40^{\text {th }}$ centile & 0.690 & 0.810 & 0.180 & 4.560 & 0.000 & 0.460 & 1.160 \\
\hline $50^{\text {th }}$ centile & 0.770 & 0.750 & 0.160 & 4.530 & 0.000 & 0.430 & 1.100 \\
\hline $60^{\text {th }}$ centile & 0.790 & 0.740 & 0.160 & 4.520 & 0.000 & 0.420 & 1.060 \\
\hline $70^{\text {th }}$ centile & 0.860 & 0.690 & 0.150 & 4.490 & 0.000 & 0.390 & 0.990 \\
\hline $80^{\text {th }}$ centile & 1.280 & 0.460 & 0.110 & 4.280 & 0.000 & 0.250 & 0.680 \\
\hline $90^{\text {th }}$ centile & 2.410 & 0.110 & 0.400 & 2.700 & 0.007 & 0.030 & 0.180 \\
\hline
\end{tabular}




\section{Metal sector (24)}

Table A.3.3.a Marginal effect of R\&D on TFP gap conditional on Embedded Technology

Embedded

technology

mean

$10^{\text {th }}$ centile

$20^{\text {th }}$ centile

$30^{\text {th }}$ centile

$40^{\text {th }}$ centile

$50^{\text {th }}$ centile

$60^{\text {th }}$ centile

$70^{\text {th }}$ centile

$80^{\text {th }}$ centile

$90^{\text {th }}$ centile

$\begin{array}{rl}\text { coefficient } & \text { se } \\ 0.085 & 0.15 \\ 0.13 & 0.19 \\ 0.12 & 0.18 \\ 0.1 & 0.16 \\ 0.1 & 0.16 \\ 0.1 & 0.16 \\ 0.07 & 0.13 \\ 0.06 & 0.13 \\ 0.06 & 0.12 \\ 0.05 & 0.12\end{array}$

95\% confidence interval, lower value

1.76

1.52

1.59

1.66

1.68

1.71

1.88

1.91

1.93

1.96 p-value

$$
\text { z st. }
$$

0.57

0.69

0.565

0.493

0.66

0.510

0.63

0.531

0.62

0.536

$0.6 \quad 0.545$

$0.5 \quad 0.614$

$0.48 \quad 0.629$

0.46

0.644

$0.44 \quad 0.658$
95\% confidence interval, upper value 0.376

0.42

0.40

0.32

0.31

0.30

$-0.19$

0.29

Table A.3.3.b Marginal effect of Embedded Technology on TFP gap conditional on own R\&D

\begin{tabular}{cr}
\multicolumn{2}{c}{ Own R\&D } \\
mean & 0.31 \\
$10^{\text {th }}$ centile & 0.130 \\
$20^{\text {th }}$ centile & 0.130 \\
$30^{\text {th }}$ centile & 0.150 \\
$40^{\text {th }}$ centile & 0.170 \\
$50^{\text {th }}$ centile & 0.210 \\
$60^{\text {th }}$ centile & 0.240 \\
$70^{\text {th }}$ centile & 0.290 \\
$80^{\text {th }}$ centile & 0.440 \\
$90^{\text {th }}$ centile & 0.300
\end{tabular}

\begin{tabular}{rr} 
coefficient & \multicolumn{1}{l}{ se } \\
0.14 & 0.46 \\
0.400 & 0.730 \\
0.400 & 0.730 \\
0.350 & 0.680 \\
0.310 & 0.640 \\
0.250 & 0.580 \\
0.210 & 0.530 \\
0.160 & 0.480 \\
0.034 & 0.350 \\
-0.110 & -0.206
\end{tabular}

z st.

p-value

0.30

0.765

0.550

0.585

0.550

0.585

0.510

0.607

0.490

0.627

0.440

0.663

0.696

0.330

0.741

0.100

0.923

$-0.560 \quad 0.577$
95\% confidence interval, lower value

$-0.767$

$-1.040$

$-1.040$

$-0.980$

$-0.940$

$-0.880$

$-0.840$

$-0.790$

$-0.660$

$-0.518$
95\% confidence interval, upper value
0.289 


\section{Food sector (10)}

Table A.3.4.a Marginal effect of R\&D on TFP gap conditional on Embedded Technology

Embedded

technology

mean

$10^{\text {th }}$ centile

$20^{\text {th }}$ centile

$30^{\text {th }}$ centile

$40^{\text {th }}$ centile

$50^{\text {th }}$ centile

$60^{\text {th }}$ centile

$70^{\text {th }}$ centile

$80^{\text {th }}$ centile

$90^{\text {th }}$ centile

1.07
0.7
0.94
0.99
1.02
1.07
1.2
1.23
1.25
1.26

co

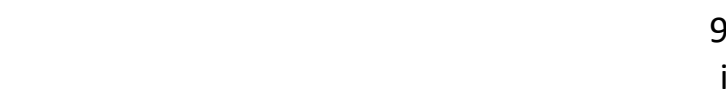

95\% confidence

interval, lower

value

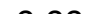

$$
9.7
$$

15

0.43

0.68

22.6

22.7

0.000

0.000

22.7

0.000

10.7

0.51

22.68

0.000

9.66

0.45

22.7

0.000

8.15

22.7

0.000

22.7

0.000

0.000

7.66

0.34

22.7

22.7

0.33

0.000
95\% confidence interval, upper value 8.86

14.0

10.5

9.8

9.4

8.8

7.4

7.1

7.0

6.9
10.54

16.7

12.5

11.6

11.2

10.5

8.8

8.5

8.3

8.2

Table A.3.4.b Marginal effect of Embedded Technology on TFP gap conditional on own R\&D

\begin{tabular}{|c|c|c|c|c|c|c|c|}
\hline \multicolumn{2}{|c|}{ Own R\&D } & coefficient & se & z st. & $p$-value & $\begin{array}{c}95 \% \text { confidence } \\
\text { interval, lower } \\
\text { value }\end{array}$ & $\begin{array}{c}95 \% \text { confidence } \\
\text { interval, upper } \\
\text { value }\end{array}$ \\
\hline mean & 0.19 & 24.6 & 1.13 & 21.82 & 0.000 & 22.39 & 26.8 \\
\hline $10^{\text {th }}$ centile & 0.03 & 48 & 2.2 & 21.9 & 0.000 & 43.8 & 52.4 \\
\hline $20^{\text {th }}$ centile & 0.05 & 43 & 1.9 & 21.9 & 0.000 & 38.9 & 46.6 \\
\hline $30^{\text {th }}$ centile & 0.14 & 29 & 1.3 & 21.8 & 0.000 & 26.6 & 31.8 \\
\hline $40^{\text {th }}$ centile & 0.16 & 27 & 1.24 & 21.8 & 0.000 & 24.7 & 29.6 \\
\hline $50^{\text {th }}$ centile & 0.19 & 24.9 & 1.14 & 21.8 & 0.000 & 22.6 & 27.1 \\
\hline $60^{\text {th }}$ centile & 0.24 & 21.7 & 0.99 & 21.8 & 0.000 & 19.8 & 23.7 \\
\hline $70^{\text {th }}$ centile & 0.27 & 20 & 0.93 & 21.8 & 0.000 & 18.5 & 22.1 \\
\hline $80^{\text {th }}$ centile & 0.29 & 19 & 0.88 & 21.8 & 0.000 & 17.4 & 20.8 \\
\hline $90^{\text {th }}$ centile & 0.3 & 18 & 0.8 & 21.8 & 0.000 & 16.7 & 20.1 \\
\hline
\end{tabular}


Table A4. The construction of the R\&D embedded technology variable

- From the World Input-Output Database (http://www.wiod.org/home) we have collected the value of transactions from one industry of a country to another industry of the same or another country year by year between 2000 and 2014 (Input-Output matrix).

- Next, we collect data on EU 28 countries and the value of transactions for four manufacturing sectors: computing, chemicals, basic metal and food.

- For each combination of receiving sector, country and year (e.g. "computing" Germany in 2005) we have computed the relative weight of the transactions from all sectors (2digits) in the total transactions value. This shows the relative importance of the value of the transactions from different sectors into four "target" sectors.

- Finally, we have multiplied each relative weight (sector, country year specific) by the OECD Taxonomy of Economic Activities Based on R\&D Intensity, \% of Gross Value Added (GVA). See Galindo-Rueda and Verger (2016), see table 1 page 10.

- The results is the percentage of R\&D on GVA imported from other technology-weightedsectors within the European Union (including domestic).

\begin{tabular}{|r|l|l|}
\hline $\begin{array}{l}\text { ISIC } \\
\text { rev4 }\end{array}$ & $\begin{array}{l}\text { OECD taxonomy } \\
\text { of Economic } \\
\text { activity based } \\
\text { on R\&D } \\
\text { Intensity }\end{array}$ & Industry Description \\
\hline 72 & 30.39 & Scientific research and development \\
\hline 21 & 27.98 & $\begin{array}{l}\text { Manufacture of basic pharmaceutical products and } \\
\text { pharmaceutical preparations }\end{array}$ \\
\hline 26 & 24.05 & Manufacture of computer, electronic and optical products \\
\hline 29 & 15.36 & Manufacture of motor vehicles, trailers and semi-trailers \\
\hline 28 & 7.89 & Manufacture of machinery and equipment n.e.c. \\
\hline 20 & 6.52 & Manufacture of chemicals and chemical products \\
\hline 27 & 6.22 & Manufacture of electrical equipment \\
\hline $62 \_63$ & 5.92 & $\begin{array}{l}\text { Computer programming, consultancy and related activities; } \\
\text { information service activities }\end{array}$ \\
\hline 30 & 5.72 & Manufacture of other transport equipment \\
\hline 22 & 3.58 & Manufacture of rubber and plastic products \\
\hline $31 \_32$ & 2.85 & Manufacture of furniture; other manufacturing \\
\hline 23 & 2.24 & Manufacture of other non-metallic mineral products \\
\hline 24 & 2.07 & Manufacture of basic metals \\
\hline 33 & 1.93 & Repair and installation of machinery and equipment \\
\hline 71 & 1.78 & $\begin{array}{l}\text { Architectural and engineering activities; technical testing and } \\
\text { analysis }\end{array}$ \\
\hline 73 & 1.78 & Advertising and market research \\
\hline 74 75 & 1.78 & $\begin{array}{l}\text { Other professional, scientific and technical activities; } \\
\text { veterinary activities } \\
\text { Legal and accounting activities; activities of head offices; } \\
\text { management consultancy activities }\end{array}$ \\
\hline 69 70 & 1.76 & Manufacture of paper and paper products \\
\hline 17 & 1.65 & \\
\hline
\end{tabular}




\begin{tabular}{|c|c|c|}
\hline 13_15 & 1.59 & Manufacture of textiles, wearing apparel and leather products \\
\hline 61 & 1.45 & Telecommunications \\
\hline 10_12 & 1.44 & $\begin{array}{l}\text { Manufacture of food products, beverages and tobacco } \\
\text { products }\end{array}$ \\
\hline 25 & 1.19 & $\begin{array}{l}\text { Manufacture of fabricated metal products, except machinery } \\
\text { and equipment }\end{array}$ \\
\hline 19 & 1.17 & Manufacture of coke and refined petroleum products \\
\hline 05_09 & 0.8 & Mining and quarrying \\
\hline 16 & 0.7 & $\begin{array}{l}\text { Manufacture of wood and of products of wood and cork, } \\
\text { except furniture; manufacture of articles of straw and plaiting } \\
\text { materials }\end{array}$ \\
\hline 18 & 0.67 & Printing and reproduction of recorded media \\
\hline 58 & 0.57 & Publishing activities \\
\hline 64 & 0.38 & $\begin{array}{l}\text { Financial service activities, except insurance and pension } \\
\text { funding }\end{array}$ \\
\hline 65 & 0.38 & $\begin{array}{l}\text { Insurance, reinsurance and pension funding, except } \\
\text { compulsory social security }\end{array}$ \\
\hline 66 & 0.38 & Activities auxiliary to financial services and insurance activities \\
\hline 35 & 0.35 & Electricity, gas, steam and air conditioning supply \\
\hline 36 & 0.35 & Water collection, treatment and supply \\
\hline 37_39 & 0.35 & $\begin{array}{l}\text { Sewerage; waste collection, treatment and disposal activities; } \\
\text { materials recovery; remediation activities and other waste } \\
\text { management services }\end{array}$ \\
\hline 59_60 & 0.32 & $\begin{array}{l}\text { Motion picture, video and television programme production, } \\
\text { sound recording and music publishing activities; programming } \\
\text { and broadcasting activities }\end{array}$ \\
\hline 41_43 & 0.28 & Construction \\
\hline 45 & 0.28 & $\begin{array}{l}\text { Wholesale and retail trade and repair of motor vehicles and } \\
\text { motorcycles }\end{array}$ \\
\hline 46 & 0.28 & Wholesale trade, except of motor vehicles and motorcycles \\
\hline 47 & 0.28 & Retail trade, except of motor vehicles and motorcycles \\
\hline 1 & 0.27 & $\begin{array}{l}\text { Crop and animal production, hunting and related service } \\
\text { activities }\end{array}$ \\
\hline 2 & 0.27 & Forestry and logging \\
\hline 3 & 0.27 & Fishing and aquaculture \\
\hline 77_82 & 0.18 & Administrative and support service activities \\
\hline 84 & 0.18 & Public administration and defence; compulsory social security \\
\hline 85 & 0.18 & Education \\
\hline $86 \_88$ & 0.18 & Human health and social work activities \\
\hline 94_96 & 0.11 & Other service activities \\
\hline 97_98 & 0.11 & $\begin{array}{l}\text { Activities of households as employers; undifferentiated goods- } \\
\text { and services-producing activities of households for own use }\end{array}$ \\
\hline 99 & 0.11 & Activities of extraterritorial organizations and bodies \\
\hline 49 & 0.08 & Land transport and transport via pipelines \\
\hline 50 & 0.08 & Water transport \\
\hline 51 & 0.08 & Air transport \\
\hline
\end{tabular}




\begin{tabular}{|r|l|l|}
\hline 52 & 0.08 & Warehousing and support activities for transportation \\
\hline 53 & 0.08 & Postal and courier activities \\
\hline $55 \_56$ & 0.017 & Accommodation and food service activities \\
\hline 68 & 0.008 & Real estate activities \\
\hline
\end{tabular}

